\title{
Purkarthofer Kornél
}

\section{Az óészaki kultúra nyomai a modern fantasy-irodalomban: Tolkien és a skandináv mitológia*}

A dolgozat elsősorban J. R. R. Tolkien életmüve és a skandináv mitológia közötti párhuzamokat kutatja. Vitathatatlan, hogy napjainkban széleskörü népszerüségnek örvend a vikingkori északi pogány hiedelemvilág a fantasy különbözö közegein belül, mely az utóbbi évtizedekben kinőtte eredetileg kizárólag irodalmi müfajként betöltött szerepét, és egyfajta kulturális jelenséggé vált. Ahhoz azonban, hogy megérthessük, Tolkien maga hogyan vett részt ebben a folyamatban, és milyen kapcsolatot is ápolt a nevezett mitológiával, szükséges magyarázattal szolgálni bizonyos fogalmakat illetően. A dolgozat első fejezetei a fantasztikus irodalommal és annak manapság legismertebb müfajával, a modern fantasyvel foglalkoznak részletesebben, továbbá itt kerül sor Tolkien és forrásai, az óészaki kultúra, az Eddák, valamint az óizlandi sagák elhelyezésére is. A dolgozat második fele arra koncentrál, milyen tudományos-irodalmi tevékenység áll Tolkien 20. századi (mü)mitológiájának hátterében, és hogyan jeleníti meg a múlt század egyik legismertebb alkotója, a „high-fantasy atyja” az óészaki kultúra és skandináv mitológia elemeit saját, divatot teremtő történeteiben.

Kulcsszavak:

irodalomtudomány, fantasy, skandináv mitológia, óészaki kultúra, J. R. R. Tolkien

This paper examines parallels between the oeuvre of J. R. R. Tolkien and Norse mythology. Undoubtedly, the pre-Christian Nordic religion of the Viking Age enjoys immense popularity among the various communities of fantasy culture which, in the last few decades, has outgrown its original role as a strictly literary genre and become a cultural phenomenon on its own. However, in order to understand how Tolkien took part in and shaped this process, and to what extent he was indebted to the aforementioned mythology, we must come to terms with a set of definitions. The first section of the paper sets out to thoroughly analyze fantastic literature and its most ubiquitous genre, the modern fantasy, with regard to the contextualization of Tolkien and his sources, Old Norse culture, the Eddas, as well as the Old-Icelandic Sagas. The second part concentrates on the academic-literary work behind the 20th century (pseudo)mythology of Tolkien, a most influential figure in the history of high-fantasy, and how he portrays Old Norse culture and mythology in his trend-setting stories.

Keywords: literary studies, fantasy, Norse Mythology, Old Norse culture, J. R. R. Tolkien

\section{A skandináv mitológia reneszánsza}

Odin, Thor, Loki, Asgard, Ragnarök, vikingek, kardok, pajzsok, kalapácsok, hajók, portyák, Valhalla, Világkígyó, Világfa és hasonlók - ki ne hallott volna ezekről a szavakról és kapcsolatukról manapság? A skandináv mitológia és az északi pogányság (vikingek) iránti

\footnotetext{
* A tanulmány témavezetője Domsa Zsófia.
} 
érdeklődés egyre növekvő intenzitással szilárdítja meg - mára már vitathatatlanná vált helyét és szerepét napjaink szórakoztatóiparában. A fantasy-irodalomban, a hollywoodi filmiparban, a virtuális játékok és táblás szerepjátékok világában, de még a zenei életben is feltűnő jelenség a skandináv mitológia és szereplőinek, helyszíneinek és egyéb kisebbnagyobb mértékben ismert elemeinek felvonultatása.

A filmiparon belül érdemes megemlíteni a Marvel filmstúdió alkotásait (például „Thor” vagy „The Avengers” [Bosszuállók]) vagy a világhírű HBO-sorozatot, a „Vikingek”-et, mely a legendás dán viking, Ragnar Lothbrok élettörténetét dolgozza fel. Ezek a filmek kifejezetten a skandináv mitológia elemeit, a középkori Skandinávia hitvilágát és mindennapjait veszik alapul, de olykor sokkal rejtettebb elemeket tartalmazó „északi ihletésü” filmekkel is találkozunk: ilyen elemeket figyelhetünk meg például a Disney stúdió által készített, világhírre szert tett „Frozen” [Jégvarázs] című animációs filmben, mely nem csupán északi tájakkal, tematikákkal, karakterekkel, nevekkel és egyéb motívumokkal dolgozik, de vikingkori szövegekből származó idézeteket, vikingkori rituálékat mutat be, sőt, még a fiatalabb vikingkori rúnaábácét $(F U T H A R K)$ is szerepelteti egy rövid jelenet erejéig. Külön érdekesség, hogy a Disney stúdió egy kaliforniai professzor, Jackson Crawford segítségét vette igénybe, akinek az óizlandi nyelv és kultúra a szakterülete, és aki az elmúlt évben tett szert viszonylag nagy követőtáborra a YouTube-on, ahol saját csatornáján a vikingkori társadalomról, valamint magáról az óizlandi nyelvről készített videóiban igyekszik tudását megosztani az érdeklődőkkel. Ugyanezen a csatornán számol be arról, milyen segítséget nyújtott a Jégvarázs elkészítéséhez, és milyen apróbb meglepetésekkel találkozhat a figyelmes néző: ${ }^{1}$ megemlíti a király és a királynő sírkövén található rúnafeliratot, ${ }^{2}$ valamint az egyik jelenet hátterében látható könyvet, melynek fedőlapján a „Rúnar fjǫllkunnigra” [A bölcsek rúnái] cím olvasható.

A videójátékok között első helyen említhetjük a világhírü „Warcraft”-szériát, az „Age of Mythology”-t, a táblás szerepjáték változattal is rendelkező „Dungeons \& Dragons”-t vagy éppen napjaink egyik legnagyobb sikerét, az „The Elder Scrolls” sorozat ötödik részét, a „Skyrim” névre hallgató szerepjátékot, melyek elsődleges ihletforrása Tolkien munkássága és a skandináv mitológia volt, és melyek nem ritkán eredeti óészaki kifejezéseket kölcsönözve mutatja be az „Eddák”, az óizlandi sagák - melyeket a továbbiakban részletesen fogunk tárgyalni - és az északi hősök világát a klasszikus fantasy-elemek felhasználásával.

\footnotetext{
${ }^{1} \mathrm{https}: / /$ www.youtube.com/watch?v=cY7Xo6AYWfI (24.03.2017)

2 „Agnarr konungr hann dó í hafi. Iðunn dróttning hon dó í hafi.”” („Agnar király, aki tengeren halt meg, és Iðun királynő, aki szintén a tengeren halt meg.")
} 
Talán még a fentieknél is egyértelmübb nyomait láthatjuk az említett tendenciának a kortárs skandináv zenei életben. A különböző folk és metál együttesek között mindenféle nehézség nélkül találhatunk olyan elöadó- és együttesneveket, albumcímeket és zeneszámokat, melyeket a skandináv mítoszok ihlettek. A teljesség igénye nélkül sorolhatunk itt fel olyan együtteseket, mint a Myrkvidr, a Skálmöld, az Angantyr, az Ásmegin, vagy a Wardruna, és olyan album címeket, mint például az utóbbi együttes Gap Var Ginnuga, Yggdrasill és Ragnarök (együttesen: Runaljod-trilógia), melyek a skandináv rúnákról, a világfáról, illetve a világvégéröl kapták nevüket, csakúgy, mint a rajtuk található egyes zeneszámok.

Úgy tünik, a skandináv mitológia a maga egzotikumával talán az egyetlen olyan kulturális hagyaték az európai pogány korokból, amely ma széles körü ismertségnek örvend a klasszikus (görög és római) mitológiákon kívül. Ráadásul - a klasszikus mitológiákkal ellentétben - a skandináv mitológia nem képezi a középiskolás tananyag részét: ismertségének és népszerüségének okait tehát máshol kell keresnünk. Egyértelmü, hogy a viking kultúra és a kereszténység előtti Skandinávia hitélete (mint érdekesség) túlnyomórészt az elmúlt évtizedekben kialakult populáris irodalomban (főként az ún. fantasy-irodalomban) bukkant fel, majd az irodalomból kiindulva a szórakoztatóipar már említett egyéb ágazataira is átterjedt. Ez azonban nem mindig volt így, bár a skandináv mitológia korántsem először játszik fontos szerepet az európai kultúrában.

A 19. századi nemzeti romantikák korában Skandináviában is megindult (főleg angol és német hatásra) a nemzeti öntudat, a közös múlt, a „saját” kutatása, aminek jelentős részét képezte a saját nép mitológiájának kutatása. A skandináv nemzeti romantika megalapozója Nicolai Fredrik Severin Grundtvig (1783-1872) dán író, történész és reformátor volt, aki elsőként tárgyalta az egységesített skandináv mitológiát az óhéber és görög mintákat követő „Nordens Mythologi” [Észak mitológiája, 1832] címü müvében (Király 1988: VIII, 18-19). Ez a mű kulcsfontosságú szerepet játszott mind a 19. századi skandináv szellemi életben, mind a későbbi korokban, ugyanis a skandináv mitológiát érintő ismereteink első és fő rendezett forrása. A svéd, norvég, dán és izlandi irodalmi életben is főszerephez jutottak a saját mitológiát feldolgozó alkotások. Maga Grundtvig is felhasználta a skandináv mitológia egyes elemeit (kontextustól függetlenül) nem mitologikus tárgyú költeményeiben, csakúgy, mint honfitársa, a nagy dán romantikus Adam Oehlenschläger (1779-1850) vagy a svéd nemzeti eposz, a „Frithiofs saga” [Frithiof-monda, 1825] megírója, Esaias Tegnér (17821846) (Olsson/Algulin 1995: 210). De ide tartozik az izlandi Jónas Hallgrímsson (1807-1845) és Bjarni Thorarensen (1786-1841) is, akik másképp alkalmazták elődjeik mitológiájának elemeit: nem programszerüen, a nemzeti öntudat kialakítása céljából, hanem sokkal inkább 
azok egzotikus, érdekes vonásait hangsúlyozva. Ugyanakkor meg kell jegyezni, Izlandon mindig is másképpen viszonyultak a közös nemzeti múlt, az óészaki kultúra hagyatékához, ugyanis nekik jóval szorosabb kapcsolatuk volt e hagyománnyal, mely kultúrájuk és irodalmuk szerves részét képezi a középkor óta (Lassen 2008: 105-108).

19. század első felében a skandináv mitológia egyértelmüen a kultúra felső rétegéhez, az úgy nevezett „magas irodalomhoz” tartozott: a skandináv költők és írók feladatuknak érezték a közös, dicső múlt emlékének és mítoszainak „felélesztését” és őrzését. Irodalmi körök, „,intellektuális klubok” alakultak a skandináv mitológia ünneplésének szellemében. Ilyen volt például a svéd uppsalai egyetem körül kialakult és saját irodalmi folyóirattal rendelkező Auroraförbundet, de a stockholmi Götiska förbundet is, melynek tagjai (akik gyakran viking nevet, illetve egy-egy mitologikus alak nevét vették fel becenévként) rendszeres összejövetelek keretein belül irodalomról, mitológiáról, a svéd (és skandináv) szellemi élet jelenségeiről, eseményeiről tárgyaltak, miközben a vikingek híres italát, a mézsört (mjöðr) fogyasztották (Olsson/Algulin 1995: 182).

A 19. század második felében, a realizmus (és Skandináviában a modern áttörés) ${ }^{3}$ megjelenésével a skandináv mitológia háttérbe szorult az irodalmi életben. Bár el sosem tünt, mégis joggal állíthatjuk, hogy szélesebb körü népszerüségre (a tudományos kutatásokat leszámítva, melyek a 19. századtól folyamatosan egyre bővültek az óészaki hagyományt illetően egész Európában, az Egyesült Államokban, sőt, Ázsiában is) a romantika óta csak az utóbbi néhány évtizedben tett szert (Voigt 2016: 12). Mégpedig a már említett populáris kultúrában, elsősorban a fantasztikus irodalmon és filmiparon belül, majd az 1980-as évek kezdetével egyre inkább a virtuális játékok és szerepjátékok keretein belül érte el. Ez viszont hosszú, csaknem százéves folyamat eredménye: egy olyan folyamaté, amely a 20. század során fokozatosan kitermelte a fantasyt mint önálló müfajt és jelenséget, és amelyben kulcsfontosságú, úttörő szerepet játszott az az angol író és filológus, akinek a nevéhez helytelenül, de gyakran és nem minden ok nélkül a „fantasy megteremtője” vagy „a fantasy atyja” jelzőt szokás kapcsolni: John Ronald Reuel Tolkien.

Tolkien korántsem az első fantasy-író (hogy mennyiben fantasy-író egyáltalán, azt a továbbiakban meglátjuk), és nem is felel közvetlenül azért, hogy éppen a skandináv mitológia és a germán hagyomány ennyire áthatóan jelen van mindennapjainkban, s hogy ekkora népszerüségnek örvend a populáris kultúrában. Tudományos és irodalmi tevékenységében (mind a „magas”, mind az „alacsony irodalom” terén) azonban meghatározó szerepet játszott

\footnotetext{
${ }^{3}$ A dán Georg Brandes (1842-1927) nevéhez füződő irodalmi mozgalom, melynek célja a romantikával való leszámolás és a skandináv irodalom felzárkóztatása az európai (angol, német, francia) mezönyhöz.
} 
érdeklődése az óészaki kultúra iránti, melynek nyomai már egészen korai müveiben is fellelhetők. Ezek az nyomok, északi elemek az évek során annyira szilárd, nélkülözhetetlen komponenseivé váltak a Tolkien utáni, 20. századi (modern) fantasy-irodalomnak, melyet nem utolsó sorban a fogyasztók igényei formáltak, hogy elkerülésük bármely fantasy-író számára lehetetlenné vált. Tolkien - a modern fantasy csakugyan megkerülhetetlen alakja - az első (és talán egyetlen) olyan mitológiát alkotó író volt, aki behatóan ismerte az óészaki kultúrát és irodalmat, és aki szánt szándékkal (föleg önmaga szórakoztatása céljából) emelt át kisebb-nagyobb elemeket többek között a skandináv mitológiából saját, 20. századi „modern mümitológiájába" - ezáltal biztosítva létjogosultságot a germán vonásoknak a fantasy müfaján belül, legyen szó akár high fantasyről, akár low fantasyröl. E dolgozat célja elsősorban a skandináv mitológia 20. századi reneszánszának kutatása Tolkien munkásságán keresztül és annak vizsgálata, milyen szerepet játszott (és játszik) Tolkien életmüvében, hogyan lépett (és lép) színre a vikingkori északi hiedelemvilág a 20. századi „fantasztikus irodalomban".

\section{A skandináv mitológia forrásai, az óészaki kultúra}

A skandinávok történetileg a germánság északi ágához tartozó népek. A germánság az indoeurópai nyelvcsalád nyugati ágához tartozik, korai történetüket tekintve megkülönböztethetünk ősgermán (i.e. 1200-300) és közgermán (i.e. 300 - i.sz. 500) kort (Hutterer 1986: 50). Nem egyértelmü, pontosan hol is volt a germán őshaza, de a manapság leginkább elfogadott álláspont szerint a mai Németország északi, illetve Skandinávia déli részein alakulhatott ki. Az egyes germán törzsek időszámításunk első pár évszázada során váltak szét, majd északról kiindulva a 2-4. században fokozatosan egyre nagyobb befolyást szereztek Európában (Hutterer 1986: 45-49). Meglepő, hogy bár a Nyugat-római Birodalom bukását követően egész Nyugat-Európában egyfajta germán hegemónia alakult ki, és a germánok keleten is egyre meghatározóbb tényezővé váltak (gondoljunk a svéd vikingek birodalomalapító tevékenységeire a mai Oroszország területén), mégsem a germán kultúra vált meghatározóvá a középkor során (Mácsik 2012: 5). Ennek egyik legfőbb oka a kereszténység gyors terjedése, annak összeegyeztethetetlensége a korábbi hiedelmekkel. Európában az új hit - már pusztán földrajzi okokból is - legkésőbb Skandinávia térségében terjedt el (Dániát, Norvégiát, Svédországot és Izlandot ideértve), így ott maradhatott meg legtovább az északi-germán mitológia hagyománya. Mivel ekkor még nem alakult ki az írásbeliség, a különböző, nagy részben a közös germán korban gyökerező mítoszokat vagy egyáltalán nem írták le, vagy csak később, a kereszténység felvétele után, ekkor pedig a 
szerzetesek kihagyták vagy átalakították a pogány szokásokra, hiedelmekre utaló részeket az erőszakos hittérítésekről és a pogány szokások tiltásáról nem is beszélve. A 9-10. században, főként a norvég vikingek által betelepített Izlandon egy rendkívül sajátos helyzet állt elö: pontosan 1000-ben az izlandi népgyülés (Althing/Alpingi) demokratikus úton és kompromisszumos megoldást keresve megszavazta a kereszténységre való áttérést, így az békésen ment végbe, lehetőséget hagyva arra, hogy tiszteletben tartsák a korábbi hagyományokat is (Hutterer 1986: 133). A kereszténység pedig elhozta az írásbeliséget, így tehát lehetőség nyílt a régi történetek, költemények lejegyzésére - immár latin betűkkel, de anyanyelven: óizlandiul. Ezen lejegyzések közül mindenképpen megemlítendő a kódexekből ránk maradt két „Edda”.

A „Próza-Edda” és a „Verses Edda” az óészaki mitológia, a germánság hősmondáinak elsődleges és legösszefüggőbb forrásait nyújtják számunkra, melyeknek köszönhetően nagyjából egységes képet tudunk alkotni a skandináv mitológiáról, még ha ez a kép közel sem ellentmondásmentes. A skandináv mitológia (a Skandináviában élő germán népek mitológiája, mely a közgermán kor után a közös hagyomány bizonyos elemeit megőrizve önállóan fejlődött tovább) semmiképpen sem felcserélendő a germán mitológiával, utóbbi ugyanis még azon közös germán mítoszok összessége, melyek az északi-germánok (skandinávok) kiválását megelőzően alakultak ki. A germán mitológiáról kevés forrásunk van, legteljesebb formájában az „Eddá”-kban találkozhatunk vele, legalábbis azzal a részével, amelyet megörzött a korát tekintve jóval fiatalabb skandináv mitológia.

\section{A ,Verses Edda"}

A „Verses” (más néven „Régibb”) „Eddá”-t a 9. és 13. század között jegyezték le Izlandon, de először csak 1643-ból van tudomásunk a ma „Codex Regius” néven ismert terjedelmes kéziratról, mely egy izlandi püspök, Brynjólfur Sveinsson tulajdonába került, aki 1662-ben a dán királynak, III. Frigyesnek ajándékozta. A kéziratot 1971-ig - Izlandra történő ünnepélyes visszaszállításáig - Koppenhágában őrizték. Teljes nevén „Sæmundar Edda hins fróða”, azaz „A tudós Sæmundar Eddája” (Voigt 2016: 40) - mint később kiderült, tévesen kötötték a „legkorábbi izlandi szerző, történész”, Sæmundur Sigfússon (1056-1133) nevéhez (Király 1987: II, 949). A versek korukat és tartalmukat tekintve nem egységesek: egyes történetek akár a 4. századig is visszanyúlhatnak, míg a legkorábbi réteg akár a 13. századból származó költeményeket is tartalmazhat. Több eltérő müfajt különböztethetünk meg közöttük, ilyenek például a kviða (elbeszélő költemény), a mál (beszéd) és söngr (ének), melyek tartalmi és formai eltéréseket is mutatnak (Király 1987: II, 950). Az „Edda-dalok” szerzői, valamint 
maga az összeállító kiléte is ismeretlen, maga a versanyag - tematikáját tekintve - tartalmaz mitologikus énekeket (istenekről szóló énekek, például „Völuspá” [A jósnő szava], „Vafprúðnismál” [Vafprúðnir-ének], „Hymiskviða” [Hymir-ének]), régi germán hősi énekeket (például „Sigurð-énekek”, „Helgi-énekek”), illetve a „Codex Regius”-ban nem szereplö, de ugyanehhez a hagyományhoz köthető egyéb témájú énekeket (,vegyes énekek”, például „Grottasöngr” [Örölő], vagy „Rígspula” [Ríg-ének]), összesen harminchat darabot. ${ }^{4}$

A „Verses Eddá”-hoz tartoznak a rúnák is, melyek az északi mitológia és a vikingkori kultúra kutatásának talán legjelentősebb területét képzik. A rúnák a modern szórakoztatóipar elengedhetetlen kellékeit képzik, de tudományos kutatásuk története is visszanyúlik egészen a 18. századig: az okkultizmus, a rúnák és a rúnamisztika immár évszázadok óta képzik a germanisztika fontos részét. A modern New Age mozgalmakon kívül, egészen az 1970-es évektől kezdve világszerte alakultak olyan szervezetek, melyek a „rúnavarázzsal”, a rúnák modern misztikájával és felhasználásával foglalkoztak (és foglalkoznak). Itt azonban a rúnakutatás csupán egyetlen, radikális korszakáról érdemes szót ejteni, ugyanis ennek a korszaknak egyáltalán nem elhanyagolható a szerepe abban, hogy a 20. században a rúnák olyan fontos részévé váltak a köztudatnak és a tudományos életnek egyaránt. A germán rúnákkal való tudományos és áltudományos foglalkozás egyik tetőpontját az 1930-as években, a náci Németországban és Ausztriában érte el, ahol a germán kultúra állítólagos történeti kontinuitása vált a náci ideológia és propaganda egyik legfontosabb tárgyává. Érdekes, hogy ebben a korban fokozatosan egyre több kutatóintézmény kapott anyagi támogatást az államtól, amennyiben programjuk magába foglalta a rúnák, vagy éppen a dicsőséges német és germán múlt (ál)tudományos kutatását. A folyamat vége igen hamar az lett, hogy valamennyi állami rúnakutatási projekt szigorúan a rúnák szimbólumként való felhasználásán dolgozott (mint például az 1936-os Olimpián történő germán szimbólumok felvonultatása), és azon, hogy magyarázattal szolgáljanak arra, miként köthetők ezek a jelképek Németország és az árja nép - szintén „ragyogó és dicsőséges” - jelenéhez (Enoksen 1998: 216-218). Mindez tehát túlnyomórészt az irodalom és szigorúan véve a skandináv mitológia keretein kívül történt, így most nem is érdemes mélyebben belemerülni, számunkra elég annyit megjegyezni, hogy a germanisztikai kutatások történetében a náci időszak is mindenképpen megemlítendő - még ha a nagyszabású kutatások meglehetősen hamar el is hagyták a tudományosság talaját.

\footnotetext{
${ }^{4}$ A teljes „Verses Edda” megjelent magyarul Tandori Dezső fordításában, a „Próza-Edda” (a „Verses Edda” bizonyos verseivel együtt) magyar változata Bernáth István „Skandináv mitológia” (2011) címü müvében olvasható.
} 


\section{A „Próza-Edda”}

A „Próza-Edda” (más néven „Ifjabb Edda”) az 1220-as években keletkezett, négy nagyobb egységre osztott, ${ }^{5}$ elsősorban a „Codex Wormianus”-ban fennmaradt mű, szerzője az izlandi Snorri Sturluson. ${ }^{6}$ Mivel a „Verses Edda” legkorábban csak 1643-ban bukkant elő, sokáig úgy vélték, Snorri Sturluson „Eddá”-ja az idősebb, csak később bizonyosodott be, hogy nem a „Verses Edda” szövege emlékeztet Snorriéra, hanem fordítva: Snorri használta forrásként azokat a régi verseket, amelyeket a „Codex Regius” megőrzött (Voigt 2016: 40). A „Próza Edda” feltett szándéka volt a kor költői, a skaldok ${ }^{7}$ számára egyfajta költészeti segédanyag készítése: az idők során ugyanis sok mitológiai hagyományra épülő, pontos háttérismeretet igénylő elem (kenningek - emeletes metaforák, pl: 'Bragi lehelete'=költészet, ugyanis Bragi volt a költészet istene) mibenléte homályossá vált, tartalmuk, jelentésük már akár 80-100 év elteltével is magyarázatra szorult. Nem tudni pontosan, mit is jelent maga az „Edda” név, egyes feltételezések szerint az „ősanya” jelentésű edda szó ihlette, mások szerint az Izlandon található Oddi nevü településről kaphatta nevét, ahol az a Sæmundur Sigfússon élt, akinek egykor a „Verses Eddá”-t tulajdonították. Ezen kívül annyit tudunk, hogy a középkori izlandi irodalomban az edda szó „poétika” értelemben volt ismert, mely alatt elsősorban Snorri Sturluson költészeti kézikönyvét értették (Voigt 2016: 38-39).

Az 800-1350 közötti északi-germánság és egyben az eddikus versek nyelve az úgynevezett norrøn, melyet magyarul óészakinak szokás nevezni (Ács/Baksy 2010: 63). Ezt a nyelvi alakulatot Izlandon és Norvégiában használták egészen a 14. század közepéig, amikor is a norrøn óizlandira és ónorvégra kezdett szétválni (Ács/Baksy 2010: 82). Mivel az óizlandi nyelv (ami olyan kis mértékben tér el az újizlanditól, melyet ma használnak Izlandon, hogy gyakorlatilag egy nyelvként lehet öket kezelni [Hutterer 1986: 134]) annyira közel áll a korábbi, közös (klasszikus) óészaki állapothoz, gyakran szinonimaként használatosak ezek a fogalmak: az óészaki, óizlandi, esetenként nyugati-óskandináv kifejezések gyakorlatilag ugyanazt a nyelvet jelentik. ${ }^{8}$ Óészaki kultúra alatt általában a 8-14. századi közös északigermán (skandináv) kultúrát értjük, irodalmát és nyelvét tekintve pedig szinte kizárólag az óizlandi megnevezést szokás használni, mely elsősorban arra a nyelvre vonatkozik, amelyen a

\footnotetext{
${ }^{5}$ Prologus [Prológus], Gylfaginning [Gylfi Káprázata], Skáldskaparmál [A költészetről] és Háttatal [Verstan].

${ }^{6}$ Izlandi költő, író, politikus, történész; négy cikluson keresztül töltötte be az izlandi törvénymondó tisztségét.

${ }^{7}$ Máshol: skaldok. Királyi udvari költők, veretes költészetükre jellemző a bonyolultságra való törekvés. Minél bonyolultabban megfogalmaztak meg egy egyszerü dolog, annál nagyobb tiszteletet érdemeltek.

8 Angolszász nyelvterületen egységesen az Old Norse (esetenként az Old Icelandic) kifejezés használatos. A Norse kifejezés pontos fordítása nem létezik a magyarban, de az angol szakirodalom magát a skandináv (északigermán) mitológiát is a Norse Mythology névvel illeti. Az angolul „Nordic countries” néven emlegetett országok Dánia, Svédország, Norvégia, Finnország, Izland, Grönland és a Feröer-szigetek. Skandinávul a „Norden” szóval illetik ezt a közösséget, melyet magyarul (többé-kevésbé hivatalosan) „Északnak” nevezhetünk.
} 
szövegek íródtak. ${ }^{9} \mathrm{Ez}$ az irodalom a maga korában Európa-szerte páratlan jelenségnek számított (és számít ma is, a ránk maradt európai középkor irodalmi anyagának tekintetében). Ma három fő formáját különböztetjük meg: a „Verses Edda” mitologikus és hősi énekeit, a skaldok verseit, valamint az Izlandról származó prózai elbeszéléseket, a sagákat (Voigt 2016: 39).

Ahogy azt később láthatjuk, a 20. század első negyedétől kezdve J. R. R. Tolkien tudományos és szabadidős tevékenységének jelentős részét képezte az Eddák kutatása.

\section{A sagák}

A már említett óizlandi sagák, ${ }^{10}$ melyek az „Eddá”-k mellett jelentős inspirációforrással bírtak Tolkien számára, a 12-14. században keletkezett prózai művek, amelyek olyan, évszázadokon át szájról szájra szálló történeteket ${ }^{11}$ tartalmaznak, melyeket Izlandon írtak le. Összehasonlító irodalomtudományi és kulturális szempontból is unikálisnak tekinthetők: ilyen sokrétü, anyanyelvü prózairodalom Európában sehol máshol nem alakult ki. Bernáth István szavaival: „igazából az egész skandináv irodalomtörténet egyetlen 'paradicsomi' terepe, egyetlen eredeti és autochton hozzájárulása a világirodalomhoz.” (Király 1991: XII, 374) Felosztástól függően körülbelül 160 óizlandi nyelvü sagát ismerünk, de a töredékekkel együtt akár 200 müvet is elkülöníthetünk. Izlandon és Norvégiában mindig is ismerték őket, mind tudományos és történeti, mind szórakoztató funkciójuk használatos volt, de első modern, nyomtatott kiadásukra csak a 18. században került sor Dániában (Voigt 2016: 106-107). Müfajukat tekintve megkülönböztetünk királysagákat (konungasögur), izlandi/nemzetség sagákat (íslendingasögur), hajdankori sagákat (fornaldarsögur), valamint püspöksagákat (Biskupasögur). A kategorizálás a sagák keletkezése, cselekményük ideje és színtere, valamint tartalmuk alapján készül (Voigt 2016: 109).

A 19. és 20. század során fokozatosan egyre nagyobb teret hódított magának az óizlandi sagák kutatása (ebben a folyamatban maga Tolkien is részt vett), mégsem mondható, hogy önmagukban (a tudomány területéről kilépve) túlzottan nagy ismertségre tettek volna szert. Magyarul a már említett Bernáth István fordításában olvashatók sagák, a Corvina kiadó „Északi Források Fontes Boreales” című sorozata pedig az elmúlt pár évben kezdte meg a sagák szélesebb körben történő terjesztését. ${ }^{12}$

\footnotetext{
${ }^{9}$ Az óészaki nyelvet a 19. században normalizálták az óizlandi nyelv alapján.

${ }^{10}$ Maga a „saga” (szága) szó az óizlandi, tág értelemben használt „segja” (mondani) igéből származik.

${ }^{11}$ A szerzők kiléte gyakran ismeretlen, sokszor nem tudni, mely sagák története terjedt valóban szájról szájra, és melyek tekinthetök önálló, egy szerzöhöz köthetö alkotásnak.

${ }^{12}$ Eddig két mű jelent meg, mindkettő Bernáth István fordításában: A „Völsunga saga” és az „Egils saga”.
} 
Ezzel megtárgyaltuk azokat a fogalmakat, amelyek a továbbiakban feltétlenül szükségesek lesznek ahhoz, hogy megértsük, milyen kapcsolatot ápolt Tolkien az óészaki kultúrával, és hogyan emelte be az elsők között az általa oly kedvelt északi-germán elemeket a 20. századi fantasztikus irodalomba.

\section{A fantasztikus irodalom - Tolkien és a fantasy kapcsolata}

Csupán egyetlen dolog maradt, ami gondosabb magyarázatra szorul, mielőtt a „részletekre” térhetünk: mit is érünk fantasztikus irodalom, illetve fantasy alatt és hogyan kapcsolódik Tolkien a modern fantasy-irodalomhoz?

A fantasztikus irodalomhoz hagyományosan a természetfölötti jelenségeket valószerü környezetben, reális hősökkel együtt megjelenő szépirodalmi műveket szokás sorolni (Király 1972: II, 32). Közeli rokonmüfajai a mese, a legenda és a mítosz, de hitéletbeli szereppel nem bír. Alapeleme a fantasztikum, mely kizárólag a művön belül elhihető. A fantasztikum tudományos értelemben - nem más, mint „azon irreális, misztikus, csodás, mesés jelenségek összessége, melyeket a fantázia teremt” (Király 1972: II, 32), és amelyek, természetesen, mindig is jelen voltak az irodalomban. ${ }^{13}$ A modern fantasztikus irodalom kezdeteit a 18. század végére, majd a 19. századi romantika, a nemzeti irodalmak kialakulásának korára (föképpen angol és német nyelvterületet ideértve) szokás datálni. A 20. századi fantasztikus irodalomban a fantasztikum helyét kezdetben a science-fiction vette át, majd az 1930-as évektől kezdve, a fantasztikum fokozatos visszatértével megszülettek a tipikus, önálló modern müfajok a fantasztikus irodalmon belül (Király 1972: II, 34-35). Ilyen müfajok többek között az említett science-fiction és a fantasy, ${ }^{14}$ amely további alkategóriákra, ha úgy tetszik, önálló müfajokra osztható. Fantasy-müfajok például a „comic fantasy” (Terry Pratchett: „Discworld”), a „steampunk-kal” rokon ,gaslamp-/gaslight fantasy” (Bram Stoker: „Dracula”) vagy a „dark fantasy” (Gertrude Barrows Bennett: „Claimed”) (Ridderstrøm 2017).

A fantasztikus irodalom kutatói közül érdemes megemlíteni Tzvetan Todorov (1939-) nevét, aki az 1970-ben kiadott, „Bevezetés a fantasztikus irodalomba” című művében strukturalista megközelítéssel vizsgálja a fantasztikus irodalom, a fantasztikum mibenlétét (Omdal 2010: 17). Todorov, aki elsőként hozott nemzetközileg elismert áttörést a fantasztikus irodalom

\footnotetext{
${ }^{13}$ Az egyik leggyakrabban emlegetett klasszikus példa az Odüsszeia, melyet a „Világirodalmi lexikon” kizár a fantasztikus irodalomból, mivel ,,a fantasztikus irodalomba szükebb értelemben csak azok a müvek tartoznak, amelyek teljes terjedelmükben fantasztikus ötletre épülnek” (Király 1972: II, 32). Ezt az állítást sokan vitatják.

${ }^{14}$ Szigorúan irodalmi értelemben. A továbbiakban, egyéb kiegészítés hiányában fantasy alatt az irodalmi műfaj értendő.
} 
elméleti kutatásában, önálló műfajként tekint a fantasztikus irodalomra, melynek legfőbb kritériuma a fantasztikum jelenléte, valamint az, hogy a mü egy fiktív, de a szöveg által hihető és hiteles (rendszerint középkori atmoszférával rendelkező) ${ }^{15}$ univerzumot teremtsen, melyben az olvasó feltételezheti, hogy a szereplők, jelenségek és események valóságosak (Omdal 2010: 18). További kritériumként említi a prózaformát, valamint a szöveg szó szerint (tehát nem szimbolikusan!) történő olvasásának és értelmezésének lehetőségét (Omdal 2010: 19). Az irodalmi fantasztikum tekintetében három kategóriát különít el: a fantasztikust (,the fantastic”), a különöst („the uncanny”, „das Unheimliche”, „l'étrange”) és a csodást („the marvellous”, „le marveilleux”) (Todorov 2002: 26). A fantasztikusnak tekinthető szövegek a „tiszta különöstől” a „fantasztikus-különösön” és a „fantasztikus-csodálatoson” keresztül a „tiszta csodásig” határozhatók meg, attól függően, hogy a nem valóságos jelenségek kapnak-e racionális magyarázatot (különös - ilyen például az álom), vagy sem (csodás) (Mészöly 2015: 7-8). Todorov szerint a fantasztikum lényege az olvasó elbizonytalanítása, az, hogy az olvasó „habozzon az elbeszélt események természetes és természetfeletti magyarázata között” (Todorov 2002: 31).

\section{A fantasy}

Todorov elvei alapján azonban a legtöbb, manapság habozás nélkül fantasynek nevezett mü, nem tartozhatna a fantasztikus irodalomba, ugyanis a fantasy egyik ismert alapszabálya az, hogy eredendően egy másik világban játszódik: a csodás-varázslatos elemek, a mi világunktól való gyökeres eltérés magától értetődő, mivel a fantasy univerzuma mindig egy koherens egész, történelemmel, kultúrákkal, nyelvekkel, geográfiával (Mészöly 2015: 9). Ez a fajta „másik világ” fontos részét képzi Rosemary Jackson (1981) és Kathryn Hume (1983) fantasyről alkotott elméleteinek (Omdal 2010: 20-23). Ök nem műfajként, inkább egyfajta kifejezési módként tekintenek a fantasyre. Ha az irodalom keretein belül kívánunk maradni, a fantasyt a legegyszerübben úgy tudnánk meghatározni, mint a 20. században, az ún. fantasztikus irodalmon belül kialakult, teljes autonómiáját az 1970-es években elérő müfaj. Az utóbbi évtizedekben azonban elhagyta eddigi hatáskörét, és megkezdte térhódítását mind a „magas-”, mind a populáris kultúra szféráiban: a fantasy, ahogy a fenti definíció is mondja, „jelenséggé vált”. Ez derül ki a magyar nyelvü, fantasynek szentelt Aurin ${ }^{16}$ nevü honlap

\footnotetext{
${ }^{15}$ Ez manapság, ha egyáltalán, inkább a fantasy feltételeként szerepel bizonyos összegző listákon.

${ }^{16} \mathrm{http}: / /$ web.zone.ee/aurin/ (2016.12.29.)
} 
szerkesztősége és a Magyar Tolkien Társaság között lezajlott beszélgetésből. ${ }^{17} \mathrm{E}$ tanulságos rádióműsorból (Tolkien Világa) világosan kitünik, hogy a fantasyt nehéz pontosan definiálni, még akkor is, ha kizárólag az irodalomban elfoglalt helyét igyekszünk körülhatárolni - ahogy azt (akár helyesen, akár helytelenül) még ma is a legtöbb tudományos szemszögből közelítő fantasy-kutatás is teszi.

Kathryn Hume irodalmi, emberi és művészeti tevékenységnek tartja a fantasyt, a realizmus és a mimézis egyenrangú ellenfelének: a fantasy nem utánozza a valóságot, hanem megteremti azt. Hume és Jackson is használják a „Secondary World” kifejezést, mely alatt a „másik világot” értik, ahol az adott fantasy-mü játszódik - ennek a fogalomnak pedig Tolkien a megalkotója. Tolkien az „On Fairy-Stories”18 (1939) című esszéjében értekezik hosszasan a fantázia művészetben (elsősorban az irodalomban) betöltött szerepéről és a Fantasyről ${ }^{19}$ mint „müfajról”. Ez a kifejezés azonban korántsem helyettesíthető a mai, modern „fantasy” müfaji meghatározásával, egyrészt a fantasy-irodalom létrejöttének időbeli elhelyezése körül felmerülő problémák miatt, másrészt mivel Tolkien - szigorúan véve - nem műfajról beszélt, sokkal inkább egy olyan irodalmi jellegről, amely leginkább a mai „fantasztikus irodalom” kifejezés szinonimája lehetne. Tolkien minden bizonnyal az elsők közt volt, akik filológiai vizsgálódás tárgyává tették a Fantasy kifejezést, ${ }^{20}$ ennek ellenére nem állítható, hogy ő lett volna akár a fantasztikus irodalom, akár a fantasy müfaj megalkotója. Sőt, Tolkien - az eddig tárgyalt meghatározások alapján - nem is tekinthető fantasy-írónak, hogy miért nem, azt a későbbiekben részletesebben tárgyaljuk. De kik a fantasy tényleges megalapítói, és mióta írnak fantasyt?

\section{A fantasy születése}

A fantasy tehát olyan fikciós irodalmi müfaj, amely természetfeletti, nem valóságos elemeket sorakoztat fel, és melynek cselekménye egy fiktív, a mi világunkkal párhuzamosan, vagy attól teljesen elszakítva létező univerzumban játszódik. A szakirodalom az első fantasy-íróként

17 https://www.tolkien.hu/index.php/tolkien/item/2075-tolkien-vilaga-radiosorozat-a-fantasy-az-aurinszerkesztoi-a-fantasy-toerteneterol (2016.12.29.)

${ }^{18}$ Magyarul „A tündérmesékröl” címen jelent meg a „Szörnyek és ítészek” címen kiadott, Tolkien válogatott tudományos írásait tartalmazó gyüjteményben, először 2006-ban a szegedi Szukits kiadó jóvoltából. A továbbiakban azonban elkerülöm a magyar cím használatát, mivel Tolkien szánt szándékkal egy olyan fogalmat választott, ami addig nem létezett: a magyar „tündérmese” szó angol megfelelője a „fairytale”, amit Tolkien külön kategóriaként tárgyal részletesen, és mely egyáltalán nem cserélhető fel a tolkieni „Fairy-Story” kifejezéssel.

19 Tolkien következetesen nagy kezdőbetűvel írja a kifejezést, ezért a továbbiakban, az egyértelmüség kedvéért, minden esetben nagy kezdőbetűvel jelzem, ha a Tolkien-féle meghatározásról van szó.

${ }^{20} \mathrm{Az}$ „On Fairy-Stories” címü írásában Tolkien külön fejezetekben tárgyalja magát a „Fairy-Story” definícióját (316-331. old.) és eredetét (331-347. old.), valamint az általa használt Fantasy fogalom jelentését (361-371. old). 
gyakran a 19. századi skót írót, George MacDonaldot ${ }^{21}$ emlegeti (Omdal 2010: 191), bár fontos megjegyezni, hogy az 1970-es évek előtti fantasy-irodalom nem a mai értelemben vett modern fantasyt (mint müfajt) jelöli: a mai fantasy-irodalom (melyre gyakran azt mondjuk: „Tolkien világának vállain fekszik” [Shippey 2000]) fogalmán sok fantasy-irodalom kutató szerint kizárólag a Tolkien utáni fantasy-irodalmat értjük. ${ }^{22}$ MacDonaldon kívül két nevet érdemes megemlíteni a korai (nem modern!) fantasy-írók közül: William Morrist (18341896) és Lord Dunsanyt (1878-1954) is a fantasy első képviselői közé szokás sorolni, akik magára Tolkienra is beismerten ${ }^{23}$ mély benyomást tettek, sok értelemben mintaképként szolgáltak.

William Morris (1834-1896) angol író, költő, iparművész, afféle 19. századi polihisztor az egyik első író, akinek teljes mértékben egy kitalált világban játszódó történetei széles körben elterjedtek. Neki köszönhető a „Beowulf” mellett az óizlandi „Völsunga saga”, „Gunnlaugs saga” és „Grettis saga” angol nyelvre történő lefordítása, de ezek mellett meg kell említeni hasonlóan óészaki tematikájú, saját epikus költeményét: a „Sigurd the Volsung”-ot. Ezek a művek - valamint Morris rajongása az óészaki kultúráért - döntő szerepet játszottak Tolkien érdeklődési körének kialakulásában. ${ }^{24}$ Morris nevéhez kötik továbbá a gótikus történeteken alapuló hösi fantasy-regény müfajának megteremtését (Carter 2004: 179-181).

$\mathrm{Az}$ angol arisztokrata, Lord Dunsany, bár kevésbé népszerü, nem csekélyebb jelentőségü Morrisnál, sem a fantasy-irodalom történetének, sem Tolkien személyes forrásainak a szempontjából. Dunsany első fantasy novellagyüjteménye („Gods of Pegana”) 1905-ben jelent meg, majd ezt követően több fantasy-regényt adott ki. Óriási klasszikus műveltséggel rendelkezett, így nem lepődhetünk meg azon, hogy már néhány évvel Tolkien előtt önkényesen, „titokban” klasszikus mitológiai elemeket csempészett müveibe, látszólag kizárólag azért, mert örömét lelte felhasználásukban és átdolgozásukban. Tolkienra (és a 20. századi fantasztikus irodalomra) föleg az alternatív univerzumhoz tartozó fiktív panteon megalkotása gyakorolt nagy hatást. Az utána következő fantasy-írókon, H. P. Lovecrafton,

\footnotetext{
${ }^{21}$ George MacDonald, 1824-1905. Többek között Lewis Carroll, W. H. Auden, C. S. Lewis és J. R. R. Tolkien is elismerte, hogy müveikre meghatározó hatást gyakorolt MacDonald munkássága. Ikonikus müve: „The Princess and the Goblin" [A királykisasszony és a manó, 1872].

${ }^{22}$ Egyesek szerint egyáltalán nem is nevezhetők fantasy müveknek az 1980 elött írt müvek, ez a fantasyirodalom egy másik nagy vitájának tárgya (vö. Ridderstrøm 2017).

${ }_{23} \mathrm{https} / / / \mathrm{www} \cdot$ tolkien.hu/index.php/tolkien/item/2075-tolkien-vilaga-radiosorozat-a-fantasy-az-aurinszerkesztoi-a-fantasy-toerteneterol (2016.12.29.)

${ }^{24} \mathrm{Az}$ irodalmi hatásán kívül Morris volt az, aki Tolkient müvei illusztrálására ösztönözte. Tolkien rajzokkal, festményekkel díszítette sok müvét, leghíresebbek „A hobbit”-hoz készített illusztrációi, melyek „A hobbit müvészete" (2012) című müben szakmai kommentárok kíséretében megtekinthetők.
} 
Clark Ashton Smithen vagy éppen a legendás Conan megalkotóján, Robert E. Howardon is egyértelmüen látszik Dunsany hatása (Carter 2004: 185-188).

A modern fantasy-irodalmon belül két alapvető csoportot szokás megkülönböztetni: a high fantasyt és a low fantasyt, mely fogalmak az 1970-es években kerültek be az irodalmi köztudatba Marshall B. Tymn, Robert H. Boyer és Kenneth J. Zahorski által („Fantasy Literature: A Core Collection and Reference Guide", 1979) (Omdal 2010: 102, Lothe/Refsum/Solberg 2007: 62). Ezek a fogalmak - magához a fantasyhez hasonlóan meglehetősen homályosak, elkülönítésük gyakran problematikus. A tudományosabb megközelítés általában azt mondja, a high fantasy egy teljes, képzeletbeli világot (Secondary World) hoz létre, míg a low fantasy kapcsolatban áll a mi világunkkal akár párhuzamos valóságként, akár a mi saját, valóságos világunkba (Primary World) betörő fantasztikus elemek révén. Ezek alapján szokás high fantasy müveknek tartani például „A Gyürük Urá”-t, vagy „A tüz és jég dala”-ciklust és a „Thomas Covenant”-sorozatot, míg a low fantasy képviselőiként említhetjük a „Narnia” és a „Harry Potter” sorozatokat. A kevésbé tudományos, köznapi megközelítés az irodalmi-kulturális értéke alapján osztályoz: a high fantasy a „magas irodalom” (szépirodalom) része, magas művészi értékkel bír, míg a low fantasy (ahogy neve is mutatja) az ,alacsony”, populáris kultúrához tartozik, gyakorlatilag a ponyvaregényekhez sorolható. Tolkient szokás a „high fantasy atyja-ként” emlegetni, ez azonban meggondolatlan döntés: Tolkien - életmüvét, valamint a fantasy müfaji meghatározását figyelembe véve - nem tekinthető fantasy-írónak, legalábbis nem a hagyományos értelemben. Ahhoz, hogy megértsük, hova is sorolandó (ha egyáltalán lehetséges) Tolkien és életmüve, vizsgáljuk meg, milyen feltételei vannak a modern fantasynek, és milyen viszonyban állnak ezek Tolkien írásaival.

\section{Tolkien mitológiája}

A filológus John Ronald Reuel Tolkien (1892-1973) az angliai Oxford Egyetem professzora és a 20. század irodalmának egyik legismertebb alkotója gyerekkora óta rajongott a különböző népek mítoszaiért-mitológiáiért, a legendákért, nyelvekért, szövegekért és mindenekelőtt: a jó történetekért. Huszonhárom éves korában magas szinten tudott ógörögül, latinul, óangolul, óizlandiul, részben pedig walesi nyelven (kimru), finnül és gótul. Ekkor már két saját nyelvet is kitalált: a Nevbosht és a Quenyát. Patrióta érzületét bántotta a tény, hogy az angoloknak nem volt olyan önálló mitológiájuk, mint a görögöknek, rómaiaknak vagy éppen a germánoknak, ezért elhatározta, hogy ő ír nekik egy sajátot (Wettstein 2002, Whittingham 2008: 22-25, 34). Így kezdődött Tolkien 20. századi mümitológiájának története, melyet ő 
maga „legendáriumnak” nevezett: ${ }^{25}$ ide sorolta összes versét, novelláját, elbeszélő költeményét, regényét, mítoszát. Tolkien 1914-ben kezdett verseket, történeteket írni Középföldéről, s e tevékenységét egészen 1973-ban bekövetkezett haláláig folytatta, több tízezer oldalnyi rendezetlen kéziratot hagyva maga után, melyet azóta is életműve iránt leginkább elkötelezett fia, Christopher Tolkien kezel. Írásainak túlnyomó többsége egy kerettörténetbe (Frame Narrative) illeszkedik (Drout 2006: 216-218, Whittingham 2008: 4957): történetei egy olyan mitikus múltban játszódnak, mely a teremtéssel kezdődik, és a bibliai Ábrahám előtt ér véget (Drout 2006: 235). Tolkien életében a kereszténység talán a legnagyobb hatások közé sorolható (Whittingham 2008: 13-16), a kereszténységhez füződő kapcsolatát hosszú fejezeteken át tárgyalja a kapcsolódó szakirodalom, most azonban elég annyit megemlíteni, Tolkien alapvetően egyfajta hátteret, a bibliai hagyományoknak megfelelő „új értelmezést” kívánt alkotni, mely mindenféle értelemben a mi világunkhoz és történelmünkhöz köthető, és mely az Ábrahám előtti idők alternatív történetét tárja fel előttünk. Ábrahám ugyanis a Biblia első hiteles, történelmi személye, így Tolkien úgyszólván - teljes joggal élhetett az Ábrahámot megelőző bibliai szövegek „,metaforaként” történő értelmezésével. Ez a kerettörténet, amelybe elsősorban „A szilmarilok”, „A hobbit”, „A Gyürük Ura”, a „Befejezetlen Regék” és a „Húrin Gyermekei” című művek tartoznak, részletesen csak a Tolkien fia, Christopher Tolkien által szerkesztett tizenkét kötetes „Középfölde históriája” sorozatban ismerhető meg: a tolkieni mümitológia elsődleges és széles körben ismert forrásában („A szilmarilok”) nem esik róla szó, a történetek látszólag önálló fantasy-történetek (Whittingham 2008: 49-57). Ám ezek a történetek nem fantasy történetek: Tolkien nagyszabású történetei ${ }^{26}$ a mi saját világunkban játszódnak, ami azt jelenti, hogy a tudományos megközelítés definíciója alapján a low fantasy kategóriába kellene kerülniük. Mégsem kerültek oda, mint ahogy az sem vitatott, hogy Tolkien méltón foglal helyet a szépirodalom, ${ }^{27}$ a magas kultúra köreiben éppúgy, mint a populáris kultúrában. Tolkien épp olyan hidat képez a különböző rétegek, kultúrák, irodalmi érdeklődések között, mint amilyet kerettörténete képez a valóság és a kitalált univerzuma között. Ám az a tény, hogy „A Gyürük Urá”-ból, „A hobbit”-ból és „A szilmarilok”-ból ismert hősöket, varázslókat, lényeket és csodálatos tárgyakat bemutató kerettörténet a magunk világába helyezi mindezt,

\footnotetext{
${ }^{25}$ Az 1951-ben Milton Waldmannak írt levelében (Letter no. 131) használta először leírva a „legendárium” szót, mely alatt életművét, legalábbis az összes, saját mitológiájához kapcsolódó írását értette. Vö. Ridderstrøm 2017. ${ }^{26}$ Ide nem értve az önálló történeteket, novellákat, mint például „Leaf by Niggle” [Fa és levél, 1839], „Roverandom” (1925), „Smith of Wootton Major” [A woottoni kovácsmester 1967] vagy „Farmer Giles of Ham" [A sonkádi Egyed gazda, 1949].

${ }^{27}$ Például maga „A Gyürük Ura” is a szépirodalom kategóriában jelent meg az Európa Könyvkiadónak hála Magyarországon.
} 
nem jelenti azt, hogy Tolkien szerint ezek az írásai valóban a sok ezer évvel ezelőtti Föld állapotait mutatnák be. Ellenkezőleg: Tolkien rendkívül fontos dolognak tartotta a fantáziát és azt a képességet, hogy az ember egy teljesen önálló, alternatív valóságot tudjon létrehozni képzelőereje segítségével.

Ezeket az elveit fejti ki az „On Fairy-Stories” című esszéjében, ahol beszámol a történetek, a mesék és a fantázia jelentőségéről, az irodalomban és az életünkben betöltött meghatározó szerepéről. Itt vezeti be az azóta is gyakran felbukkanó Secondary World (Másodlagos Világ) és sub-creation/sub-creator (másodteremtés, másodteremtő) fogalmakat (Tolkien 1997: 364, 368). A Secondary World, amely fogalom Kathryn Hume modelljében is döntő fontosságú szerepet kapott, amikor a fantasy müködését, a „fantázia birodalmát” mutatja be, ahol az irreális jelenségek valóságosnak hatnak, amennyiben az ember képes másodlagos hittel (Secondary Belief) elfogadni a „másik univerzum” hitelességét és valóságát (Hume 1984: 10, Stiftler 1991: 9-10). A sub-creator (másodteremtő) magát az alkotót (legföképpen pedig az írót) jelöli, aki mủvén keresztül nyújt megújulást (Recovery - hogy friss szemmel, új perspektívából tudjuk szemlélni a világot [Tolkien 1997: 372]), menekvést (Escape - egyrészt a valóságtól, másrészt a haláltól (The Great Escape, [Tolkien 1997: 383], mely Tolkien szerint minden ember és történet meghatározó alapeleme [Tolkien 1997: 375]) és megnyugvást (Condolence - a pozitív végkimenetel, eucatastrophe [Tolkien 1997: 388] lehetősége, ha be nem is következik [Tolkien 1997: 371, 384-387]).

Egy másik, Tolkien által hangsúlyozott alapelv, hogy ezek a mesés-csodás, irreális történetek (Fantasy), illetve maga a Fantasy egyáltalán nem csak gyerekeknek való, bár említi, hogy tapasztalatai alapján a gyerekek sokkal fogékonyabbak ezen történetek önmagukban való értékelése iránt (Tolkien 1997: 347-348). Tolkien állítja, hogy minden felnőttnek jogában áll és hasznos volna ilyen történeteket olvasni - „történetként olvasni, és nem tanulmányozni!” (Tolkien 1997: 347-348) Tolkien így fogalmaz: „A Fantasy továbbra is egyike emberi jogainknak: saját mércénk szerint és az utánzás céljából teremtünk, mert mi magunk is teremtettünk: mégpedig a Teremtő képmására."28

Tolkiennak gyakorlatilag személyes missziója volt a fantázia révén egy új univerzum létrehozása. És joggal mondhatjuk, hogy ez sikerült is neki: amennyiben az „On Fairy-Tales”t programnak, elméletnek tartjuk, úgy minden okunk megvan arra, hogy az általa létrehozott mümitológiát (elsősorban „A szilmarilok”-at) hitvallása gyakorlati részének tekintsük.

28 Tolkien 1997: 371. Tolkien másodteremtés-elméletének egy erős vallási színezete is van (a Teremtés folytatása, mert Isten átruházta az emberre a teremtés képességét), amelyet ez a dolgozat nem tárgyal. 
Mümitológiája nemcsak terjedelmét és kidolgozottságát illetően ölt igen tekintélyes mértéket, de rengeteg szinten mozog egyszerre: történeteket, egész történelmeket, uralkodókat, hősöket és más személyeket, természet- és társadalom-földrajzi leírásokat, hagyományokat, nyelveket, nyelvtanokat, nyelvváltozási folyamatokat - egyszóval minden olyan elemet tartalmaz, amely elengedhetetlennek tünik egy nép alapvető megismeréséhez és megértéséhez. Tolkien nagyon is tisztában volt a mesterséges nyelvek, történelmek, esetleg egész kultúrák elképzelésének, megalkotásának veszélyeivel, nehézségeivel, éppen ezért hatalmas figyelmet fordított arra, hogy minden elem hibátlanul illeszkedjen mitológiájába: egy nép identitásérzetét nem lehet egy-két felületes leírással elintézni - szükséges az adott nép teljes hátterének ismertetése. Annak módját pedig, hogy ezt hogyan, milyen technikával, történetekkel, karakterekkel és egyéb elemekkel lehetne megvalósítani, miközben folyamatosan tartja magát a fentebb ismertetett elvekhez és a maga alkotta kerettörténethez, természetesen nem egyedül találta meg.

Tolkien rengeteg forrásból merített ihletet, elsősorban azonban az őt megelőző „fantasy-írók”, az általa oly nagyra becsült mítoszok és mitológiák, valamint saját keresztény hite bírt kulcsfontosságú hatással alkotói tevékenységére. „Legendáriumában” rengeteg nyomát látjuk mind a keresztény hitnek, mind pedig az általa csodált mitológiáknak: a görög, római, kelta, finn, de mindenekelőtt: az óészaki mítoszoknak. Lássuk hát, milyen kapcsolatot ápolt Tolkien a skandináv mitológiával, az Eddákkal, valamint óizlandi sagákkal, és hogyan emelte be elemeiket ismét a magasirodalomba, s kezdte meg terjesztésüket a 20. századi fantasyben!

\section{Tolkien és az óészaki kultúra - Sigurð és Guðrún legendája}

„Nemigen kívántam elásott kincs után kutatni, vagy kalózokkal harcolni, és a Kincses Sziget sem igazán izgatott... De Merlin és Artúr világai már jobb volt ezeknél, és mind közül legjobb Sigurd és a Völsungok ismereten Északja, és a sárkányok hercege. Ezek a világok mindennél jobban vonzottak."

J. R. R. Tolkien („On Fairy-Stories”)

J. R. R. Tolkien 1936 őszén (tehát „A hobbit” megjelenése előtt egy évvel!) „hadjáratot indított” az akadémiai filológusok és a korabeli oxfordi szemléletmód ellen „Beowulf: The Monsters and the Critics" ${ }^{29}$ címü előadásával. Amellett, hogy egy új, egészen más nézőpontból közelítő értelmezést adott a „Beowulf” nevet viselő, saját maga által is lefordított és feldolgozott óangol hőseposznak, Tolkien ebben az előadásában emel szót a hasonló

\footnotetext{
${ }^{29}$ Magyarul az előadásról elnevezett „Szörnyek és ítészek” (2006) című válogatáskötetben jelent meg.
} 
történeti-irodalmi források akkori kutatásmódja ellen. Hangsúlyozza, hogy ezek a fennmaradt, felbecsülhetetlen értékü kéziratok nem csupán történelmi „dokumentumok”, melyek vizsgálata - mégpedig a tudomány szemszögéből - kizárólag az erre kiképzett szakértők (történészek, filológusok, nyelvészek, irodalmárok) kiváltsága, hanem egyben olyan irodalmi és emberi értékekkel rendelkező, közkinccsé vált történetek is, amelyek megérdemlik, hogy bárki ismerje, olvassa, értelmezze és felhasználja őket - akár szórakozásból, szabadidős tevékenységként is. Tolkien mind a tudomány, mind a szórakozás szempontjából tekintett a hasonló, saját kutatásait érintő szövegekre, mindenekelőtt pedig az egyes népek mítoszait tartalmazó művekre: úgy vélte, ezeket a történeteket mindenkinek (elsősorban az íróknak, ,a müvészet legfontosabb képviselőinek" [Drout, 2006: 27]) jogában áll népszerüsíteni, saját müveiben feldolgozni és ezáltal életben tartani hagyományukat. Tolkien életében a legfontosabb ilyen művek a már említett „Beowulf”, a finn „Kalevala” és a két „Edda” közülük is elsősorban a „Verses Edda” - voltak, de ide tartozott az összes többi általa ismert mitológia is, melyeket együttesen a „Cauldron of Story” [Történet Üstje] gyüjtőfogalommal illetett, amikor inspirációforrásairól írt leveleiben (Whittingham 2008. 39).

\section{Tolkien professzor}

Az, hogy Tolkien író volt (legnagyobbrészt „A Gyürük Urá”-nak köszönhetően), rengeteg ember számára ismeretes. Egy fokkal kevesebben - de még így is a Tolkien nevet ismerők zöme - tudják, hogy Tolkien csak „másodállásban”, szabadidejében volt író: foglalkozását tekintve filológus, az angliai Oxford Egyetem angolszász irodalom és nyelvek tanszékének professzora volt. Ami ezzel szemben kifejezetten szük körökben köztudott, az az, hogy Tolkien oxfordi pályafutása során az „,angol irodalom professzora” mellett egy másik tisztséget is betöltött: az óészaki irodalom és nyelv professzora volt 1925-től kezdve, bár akkor hivatalosan nem is létezett ilyen cím.

Tolkien 1926 és (legalább) 1939 között évről évre előadásokat tartott az óészaki kultúráról, az óizlandi irodalomról, sagákról és az „Eddá”-król („The Elder Edda” címen) (Tolkien 2009: 14), miközben magát az óizlandi nyelvet is tanította az esetleges kíváncsiskodók számára (Tolkien 2009: 4). Aktív érdeklődése a téma iránt azonban már jóval korábban kialakult: 1920-ban, miközben az „Oxford New English Dictionary”- $\mathrm{n}^{30}$ dolgozott, elfogadta a Leeds-i Egyetem felkérését, ahol megalapította a Viking Club-ot, mely tanárokból és diákokból állt. A Viking célja a következő volt: rendszeres találkozások keretein belül sör fogyasztása, komikus

\footnotetext{
${ }^{30}$ Tolkien 1918 és 1920 között az „Oxford English Dictionary” szerkesztésében az etimológia terén vett részt. 1920-tól fontos pozíciót kapott a javított kiadás, az „Oxford New English Dictionary” elkészítésében.
} 
dalok éneklése, valamint óizlandi sagák olvasása, fordítása és értelmezése (Whittingham 2008: 20-21). Az itt megkezdett tevékenységét Tolkien az Oxfordon is folytatta: barátjával és kritikusával, C. S. Lewisszel megalapította az óizlandi nevet viselő Kolbítar (Coalbiters) csoportot, melynek tagjai Tolkien kollégái és barátai voltak, akik céljukként az Eddák és az óizlandi sagák angol nyelvre történő lefordítását tüzték ki (Whittingham 2008: 39). Érdekes, hogy ekkora lelkesedése ellenére nincs tudomásunk a témát aprólékosabban tárgyaló tolkieni publikációkról. ${ }^{31}$ Azonban az utóbbi pár évben nyilvánosságra került (ismételten Christopher Tolkien jóvoltából) két költemény, melyeket Tolkien feltehetően az 1920-as években kezdett meg és az 1930-as években fejezett be, és melyek Tolkiennak a „Verses Eddá”-hoz füződő (még az elmondottaknál is szorosabb) kötődését tükrözik: a „Völsungakviða en nýja” és a „Guðrúnarkviða en nýja”, 32

Nagymértékben William Morris fordítói-alkotói tevékenysége által fellelkesülve Tolkien elkészítette saját változatát a „Verses Edda” talán leghíresebb hősi énekéről (énekeiről), Sigurð $^{33}$ történetéről. Ezt dolgozza fel az először 2009-ben (akkor is kizárólag Angliában!) megjelent „The Legend of Sigurd and Gudrún”, mely a Tolkien-kutatás akár legújabb ígéretes fejezetének is bizonyulhat. A mü négy részét érdemes elkülönítenünk. Elsősorban a kötet szerkesztője, Christopher Tolkien bevezetőit és kommentárjait olvashatjuk, melyek az „Eddá”-kat, az óizlandi sagákat, Tolkien e témákban írt leveleit és verseit, valamint a Tolkien által is felhasznált versformákat, metrikákat tárgyalják. Ezen kívül ez az egyetlen könyv, mely tartalmazza a teljes Tolkien által írt két költeményt, melyek külön fejezetekbe kerültek, és melyeket Christopher Tolkien egymástól elkülönítve, megjegyzésekkel és magyarázatokkal ellátva tárgyal. Az olvasó részletesen megismerkedhet Tolkien forrásaival, valamint a müvek megszületésének folyamatával. A könyv végén pedig megtalálható a „Verses Edda” első, a skandináv mitológia szempontjából leglényegesebb verse, a „Völuspá”34 („The Prophecy of the Sybil" címmel) egy rímes verseléssel megalkotott tolkieni (rövidített) változata. Fontos leszögezni, hogy ezek a szövegek nem fordítások: Tolkien, ahogy azt később részletesebben is láthatjuk, több eredeti (óizlandi) nyelvű forrásból dolgozott, de átvételeket - egy-két apróbb kifejezést, szókapcsolatot kivéve - nem tartalmaznak. Gyakorlatilag más szavakkal meséli el

\footnotetext{
${ }^{31}$ Mindössze egyetlen egy jelentős akadémiai írást érdemes itt megemlíteni, a „Sigelwara Land”-et, mely egy tudományos cikk az óangol sigelwara szó etimológiájáról.

${ }^{32}$ The New Lay of the Völsungs [A Völsungok új éneke] és The New Lay of Gudrún [Az új Gudrún-ének] (Christopher Tolkien fordítása - kommentárjaiban az angol címet használja, bár ezek nem Tolkientól származnak)

${ }_{33} \mathrm{Az}$ óizlandi kifejezések megegyeznek Bernáth István „Skandináv mitológia” című művében található helyesírással. Az ismeretlen betük, betükapcsolatok kiejtése: ý: [i, í, a: [áj], ð: [d] - angol father, p: [t, sz] angol thief, á: [au], au: [öj], é: [je], ó: [ou], u: [ü], ú: [u], y: [i].

${ }^{34}$ Magyarul „A völva jövendölése” (Tandori Dezső) vagy „A jósnő szava” (Bernáth István) néven ismertek.
} 
Tolkien a „Verses Eddá”-ból ismert legendát, írása részben önálló alkotásként kezelendő, mely azonban a lehető legszorosabban kapcsolódik az óészaki hősi hagyományhoz, és mely nem tartalmaz olyan elemet, amellyel kizárólag Tolkien egészítette volna ki a több (egymásnak olykor ellentmondó) forrásból fennmaradt történetet (Tolkien 2009: 40).

\section{Sigurð és Guðrún legendája röviden}

A történetben Sigmund fia Sigurð, a hős Völsung-sarj, hatalmas vagyonra tesz szert, amikor nevelője, Regin tanácsára megöli annak Fáfnir nevezetü testvérét, aki sárkány alakjában a skandináv istenek által felhalmozott kincset (Andvari aranya) örzi. Fáfnir legyőzése után Sigurð árulásra készülő mentorával, Reginnel is végez, majd újabb kalandok után néz, majd rátalál az átokkal elaltatott Brynhild nevű valkyrjára. ${ }^{35}$ Egymásba szeretnek és esküt tesznek, hogy a jövőben egybekelnek. Egy csel révén Sigurð mégis a Gjúkungok (későbbi Niflungok) közül választ magának feleséget: Guðrúnt veszi el, aki fogadott testvéreinek, Högninek és Gunnarnak a húga. A Gjúkungok féltékenységből és Brynhild (aki közben Gunnarhoz ment férjül egy újabb cselnek köszönhetően) buzdítására később megölik Sigurðot. A hatalmas kincs, melyet Sigurð szerzett Fáfnirtól, a Gjúkungok (Niflungok) tulajdonába kerül: ezt a kincset azonban, mivel történetesen viszály tör ki köztük és egy Atli (Attila) nevü hun király között, elrejtik a Rajnában, ahonnan sosem kerül elő. A viszályban mindkét hős férfi, Högni és Gunnar is életét veszti. Sigurð az óészaki legendák, mítoszok talán legkiemelkedőbb alakja, a „Verses Edda” hét költeményének, és számos óizlandi sagának főszereplője.

Ez a történet képezi az óészaki legenda és a német Nibelung-mondakör („Nibelungenlied”) kapcsolódási pontját: a „Rajna kincse” nem más, mint az Andvari nevü törptől a skandináv istenek által elkobzott vagyon. Ennek a kincshalomnak legértékesebb darabja egy gyürü, a későbbi „Niflungok gyürüje” ( Der Ring des Nibelungen), mely egy átok következtében balszerencsét hoz tulajdonosára. ${ }^{36}$ Sigurðot követően fogadott testvérei, a Niflungok kaparintják meg a kincset, mely végül a Rajnába veszik. Christopher Tolkien megjegyzi: Richard Wagner valószínüleg ugyanazokból a forrásokból dolgozott, mint Tolkien, de hangsúlyozza, hogy míg Tolkien egyértelmüen a hagyományt folytatta, és kizárólag a történet eredeti elemeit használta fel, Wagner librettója („Der Ring des Nibelungen”) sokkal inkább egy új, önálló művészeti alkotás, mintsem az ősi hőslegenda hagyományának folytatása -

\footnotetext{
${ }^{35}$ Óđin lányai - isteni lények, akik a harcokban elesetteket szolgálják ki Óđin csarnokában, a Vallhöllben. Szó szerint: halottakat kiválasztó (Szteyblin-Kamenszkij 1985: 83).

${ }^{36}$ Egyesek (például Lin Carter) úgy vélik, ez a gyürü ihlette Tolkien Egy Gyürüjét, azonban ez az elmélet nehezen alátámasztható, mivel szinte mindegyik mitológia tartalmaz több legendás, varázserővel bíró gyürüt. Sokkal valószínübb, hogy (amennyiben valóban egyetlen mitikus gyürủ volt Tolkien inspirációforrása) az Egy Gyürü a Gilgames-eposzból ismert láthatatlanná tévő gyürủ alapján született meg.
} 
Tolkien semmilyen módon nem használta Wagner alkotását ihletforrásként (Tolkien 2009: 10). A történet feljebb említett személyei azonosak a németül Siegfried (Sigurð), Brünnhilde (Brynhild), Günther (Gunnar), Hagen (Högni) néven ismert szereplőkkel, Tolkien azonban következetesen ragaszkodott az óészaki alakokhoz, a történet skandináv vonalához.

\section{A „,Völsungakviða en nýja”}

A „Verses Edda” hősi énekei gyakorlatilag két család, a Völsungok és Niflungok története köré szerveződnek. A két család történetét összekötő alak, és egyben az „Edda-dalok” legnevesebb hőse Sigurð, aki Tolkien költeményében is központi szerepet játszik - erre utal a vers teljes címe: „Völsungakviða en nýja eða Sigurðarkviða en mesta” [A Völsungok új éneke, avagy a legteljesebb Sigurð-ének]. ${ }^{37}$ Fő forrásai a „Verses Edda” kapcsolódó énekei, valamint az óizlandi „Völsunga saga” voltak, de ezeken kívül alapos filológiai kutatómunka állt a Tolkien-féle „Sigurð-ének” hátterében (Tolkien 2009: 38). Mint ahogy egy fiával, Christopher Tolkiennal (negyven évvel a költemények megírását követően) folytatott beszélgetésből kiderül, Tolkien elsődleges célja a „Verses Eddá”-ból megismert történetszálak, történetmaradványok „egységesítése” és „megszerkesztése” volt (Tolkien 2009: 6). Tolkien az összes, a „Sigurð-ének”-ekből és a „Völsunga sagá”-ból megismert főbb szereplőt - Völsung, Sigurð, Sigmund, Signý, Sinfjötli, Andvari, Grímnir, Regin, Fáfnir, Brynhild, Guðrún, Grímhild, Gjúki, Gunnar, Högni és a skandináv mitológia egyes alakjai, mint például Óðin vagy Loki - helyszínt és eseményt felhasználta. A mű fő érdekessége, hogy Tolkien az egész művet az „Eddá”-ból ismert germán verselést, a fornyrðislagot (szó szerint: régi beszéd) alkalmazva írta meg.

Az „Edda-dalok”-ban alapvetően két jellegzetes óészaki versmértékkel találkozhatunk: a fornyrðislaggal (régi-mérték) és a ljóðaháttrral ${ }^{38}$ (dal-mérték). Az ősi germán verselés, a fornyrðislag nevét a fentebb említett Snorri Sturlusontól kapta, szabályai röviden a következők: két rövid sorból (félsor) áll össze egy hosszú sor (nagysor), egy teljes strófa pedig nyolc félsorból, azaz négy sorpárból áll. A félsorok írhatók párosával, a fornyrðislag strófák tehát ránézésre négy- vagy nyolcsorosak. A sorok szótagszáma 2-12 szótag között lehet, de egy strófán (és gyakran egész versen) belül csak rövidebb vagy csak hosszabb sorok fordulhatnak elő. Az ütemezést a versmondat két vagy három hangsúlyos szavának

\footnotetext{
37 Sigurð történetét több „Edda-dal” is tárgyalja, ilyenek például (Tandori Dezső fordításában) a „Fáfnir ölő Sigurd éneke”, a „Töredékes Sigurd-ének” és a „Sigurd-ének”. Tolkien játszik az olvasóval (és önmagával), úgy tesz, mintha az ő költeménye akár egy következő, a történetet legteljesebben elbeszélő „Edda-dal” lenne.

38 A fornyrðislagnál fiatalabb, jellegzetesen (ó)skandináv, szintén alliterációra épülö strófaforma, a skaldikus költészetre jellemzö.
} 
alliterációja adja ki. ${ }^{39}$ Egy példa erre: „Hazatért akkor / a hármas csapat, / szálmagas ászok, / szeretetre vágyók. / Fölleltek a parton / satnya két farönköt, / Körist és Repkényt, / két sorsnélkülit" ${ }^{40}$ A későbbi, szigorúbb szabályok már (nagy)soronkénti három szó alliterálását követelik meg. A fornyrðislag szabályai azonban nem kötik ki, hogy csak a mássalhangzók „alliterálhatnak”: a magánhangzók szó eleji összecsengése (asszonánc, magánhangzó rím) is megengedett, ráadásul alapszabály, hogy minden magánhangzó „rímel” az összes többivel, így ez könnyebb (és jóval ritkább) megoldás az alliterációnál.

A „Verses Eddá”-ban a versek címükkel gyakran már önmagukban jelzik müfajukat. A már említett müfajok közül (kviða, mál, söngr) a kviða az egyetlen, amely kizárólag fornyrðislagban íródott, így tehát érthető, Tolkien miért éppen a kviðát választotta saját hősi költeménye müfajául (Király 1987: II, 950).

A „Völsungakviða en nýja” másik egzotikuma, hogy Tolkien (amint már említettük) nem fordította le címét angolra, sőt, az általa megkülönböztetett tíz rész (egy bevezető, valamint kilenc fejezet) is kizárólag óizlandi címet visel, melyeket Christopher Tolkien fordított angolra:

Upphaf [Kezdet]

I. Andvara-gull [Andvari aranya]

II. Signý

III. Dauði Sinfjötla [Sinfjötli halála]

IV. Fœddr Sigurðr [Sigurðr születése]

V. Regin

VI. Brynhildr

VII. Guðrún

VIII. Svikin Brynhildr [Az elárult Brynhildr]

IX. Deild [Viszály]

Szövegrészlet (Tolkien 2009: 161-162):

Sigurd ${ }^{41} 24 \quad$ 'Yet glory no less hath Gjúki's son, my blood-brother,

\footnotetext{
${ }^{39} \mathrm{Az}$ alliteráló verselés a régi germán verselés egyik legjellegzetesebb vonása. Bár több helyen (például az óangol költészetben) fennmaradt, pusztán az alliteráció nem jelenti azt, hogy egy vers fornyrðislagban íródott.

${ }^{40}$ „Völuspá” [A jósnő szava], 17. strófa (ford. Bernáth István).

${ }^{41}$ Bár Tolkien következetesen az óizlandi helyesírást követte kéziratában, Christopher Tolkien magukban a versekben a nevek modern angol változatát használja.
} 


\begin{tabular}{|c|c|}
\hline & $\begin{array}{l}\text { best renownéd. } \\
\text { Well he loves thee, } \\
\text { lord unfearing-- } \\
\text { look now and learn } \\
\text { light yet shineth!' }\end{array}$ \\
\hline Brynhild 25 & $\begin{array}{l}\text { 'Nay, Fáfnir Sigurd } \\
\text { fearless conquered; } \\
\text { my wavering fire } \\
\text { he waded twice; } \\
\text { twice he waded } \\
\text { tongues of lightning: } \\
\text { so great glory } \\
\text { never Gunnar earned.' }\end{array}$ \\
\hline Sigurd 26 & $\begin{array}{l}\text { 'That twice he waded, } \\
\text { who told thee so? } \\
\text { Sigurd hath not said it - } \\
\text { why saist thou this?' }\end{array}$ \\
\hline Brynhild & $\begin{array}{l}\text { 'Gloom was round us. } \\
\text { Thy gleaming eyes, } \\
\text { thine eyes gleaming } \\
\text { anguish gave me }\end{array}$ \\
\hline 27 & $\begin{array}{l}\text { Veils of darkness } \\
\text { they vanquished me. } \\
\text { I am life-curséd } \\
\text { and love-bereaved. } \\
\text { Yet I curse thee too, } \\
\text { cruel forswearer, } \\
\text { who rendered to another } \\
\text { the ring taken. }\end{array}$ \\
\hline
\end{tabular}

\section{A „Guðrúnarkviða en nýja”}

Az óészaki történetet feldolgozó másik nagyszabású mü, teljes nevén a „Guðrúnarkviða en nýja eða Dráp Niflunga" [Az új Guðrún-ének, avagy a Niflungok halála] címet viselő hősi költemény a „Völsungakviða en nýja” folytatása és bizonyos tekintetben kiegészítése. Fő forrásai a „Völsunga saga” és a „Verses Edda” Attila- és Guðrún-énekei („Atlakviða”, „Atlamál”, „Guðrúnarkviða en forna”, „Guðrúnarkviða en Priðja és Guðrúnarhvöt”) (Tolkien 2009: 311-312). A történet maga a Niflung család (mellyel Sigurð házasság és vérszerződés révén került kapcsolatba) neves tagjainak (Högni, Gunnar, Guðrún) cselekedeteit és halálát beszéli el, azt követően, hogy a legendás hős, Sigurð fondorlat révén megöletett. A költemény jelentős mértékben koncentrál a férjét, Sigurðot sirató Guðrún lelki világára, a hun király (Atli/Attila) és Guðrún házasságára, valamint a Niflungok (Högni, Gunnar) és Atli közti konfliktusra, mely tragédiába torkollik. Atli feleségül veszi Guðrúnt, aki - miután férje végez bátyjaival - kegyetlen bosszút áll rajta: Guðrún megöli közös gyermekeiket, majd vérüket és 
húsukat tálalja fel urának, mielött magukra gyújtja házukat. Ez az elem egyike a különböző filmekből, könyvekből manapság is jól ismert, jellegzetesen germán fordulatoknak.

Tolkien nem osztotta fejezetekre az önmagában sokkal rövidebb lélegzetvételü „Guðrúnarkviða en nýjá’-t, de címéről ugyanaz elmondható, mint a „Völsungakviða en nýjá”ról. Metrikáját tekintve ez a költemény is kizárólag pontosan megszerkesztett fornyrðislagstrófákból áll.

Ebben a müben Tolkien határozottan kevésbé követi forrásai nyomait: több ponton eltér az eredeti történet(ek) időrendiségétől, olykor még a rokonsági kapcsolatoktól is (Brynhild esetében például), annak érdekében, hogy az olvasó ne ütközzön ellentmondásokba. Az első Gudrún-énekkel („Guðrúnarkviða en forna”) szemben, mely Tolkien változatának legelőbbre való forrása lehetett, Tolkien kihagyja a felejtést okozó bájital (melyet először az ármányos Grímhild készít Sigurð számára, ezzel elfeledtetve Brynhildnek tett házassági ígéretét, s lehetőséget teremtve arra, hogy a legendás hős az ő lányát, Guðrúnt vegye feleségül) második szerepeltetését. Ekkor, az eredeti változat szerint Grímhild lányával, Guðrúnnal itatja meg az italt, hogy elfelejtse volt férjét, és hajlandó legyen a hun Atlihoz férjhez menni. Tolkien változatában (filológiai okokból kifolyólag) Guðrún kötelességtudatból és a családja iránt érzett elkötelezettség okán engedelmeskedik anyjának, bár tudja (és ennek hangot is ad), hogy szemernyi öröme sem fog származni e házasságból, mely csak árthat neki és fivéreinek ,jóslata" be is következik (Tolkien 2009: 315-316).

A tolkieni Guðrún-ének egy másik érdekessége egy olyan elem, mely eredetileg nem jelenik meg egyik eddikus Guðrún-énekben sem: Tolkien ebben a müben használja először (de, mint később láthatjuk, nem utoljára) a „sötét erdő”, a Mirkwood jelenségét. Bizonyos „Edda-dalok” és sagák eleme az angol változattal etimológiailag azonos Myrkviðr névre hallgató misztikus, népcsoportokat elválasztó erdőség, melyet a hősi legendák emlékezete őrzött meg. Nem tudni, pontosan melyik erdőről lehet szó, valószínüleg pusztán egy mesés elem, egy-egy olyan erdőt jelezhet, ahol gonoszságokra, csapdákra kell számítani, és ahol a főhősnek kell átkelnie célja eléréséhez. Első használata minden valószínűség szerint a gótok és a hunok birodalma között elterülő erdő lehetett (Tolkien 2009: 227-228).

Szövegrészlet (Tolkien 2009: 280-281):

83 Atli sat there, anger burned him; yet murmurs mounted, men were rising.

Goths were there many: griefs they remembered, wars in Mirkwood and wars of old. 
From the hall striding

high they shouted, foes turned to friends fiercly greeted:

'Goths and Niflungs our gods helping will hew the Huns to hell's shadow!'

85 The few and fearless fiercly answered (their backs were driven to the builded walls): 'Friends, come welcome! The feast is high. Now songs let us sing of our sires of yore.'

86 Of the Goth's glory Gunnar sang there; of Iormunrek earth-shadowing king; of Angantýr and old battles of Dylgja, Dúnheid, and Danpar's walls.

E két hősi költemény tehát jól mutatja, milyen szakavatott ismerője volt Tolkien az óészaki kultúra fennmaradt forrásait, és milyen jártas volt az óizlandi irodalom és nyelv területén. De mindez pusztán a kezdet volt, az 1920-as és 1930-as évek között, saját magának szánt irományainak egyik mellékfejezete. Az óészaki kultúra elemei - főként a „Próza Eddá”-ból ismert skandináv mitológia - fő müvén, a 20. századnak szánt (mü)mitológiáján is mély, az érdeklődő szemek számára izgalmas és jól látható nyomokat hagyott, melyekkel azóta rendszeresen találkozhatunk a fantasy-kultúrába és különböző fantasy-világokba tett betekintéseink során.

\section{A skandináv mitológia elemei Tolkien mitológiájában - „A szilmarilok”}

A legtöbben azonban nem a Sigurð-legendához hasonló egzotikus költeményeiről ismerik Tolkient, aki a fentebb tárgyaltaknál jóval finomabban is építkezett az óészaki kultúra elemeiből saját mitológiája megalkotása során. A skandináv mitológia minden valószínűség szerint az összes hatás közül a leglátványosabban felfedezhető Tolkien müveiben: nyílt titok, hogy Tolkien minden forrása közül egyértelműen az „Eddá”-kat preferálta. Az alábbiakban következnek a Tolkien fő müveiben fellelhető kisebb-nagyobb átvételek: először az 
általánosabb, az egész világképet illető hasonlóságok, majd a kisebb, rejtettebb, konkrétabb átvételek.

\section{Kozmológia és teogónia}

Érdemes előre megjegyezni, hogy mivel az indoeurópai hagyományon nyugvó germán vallás politeizmusra épült, a panteont illető összehasonlítások alanyai Tolkien mitológiájának esetében a Valák lesznek, nem pedig az abszolút monoteizmust (és egyben a keresztény vallással való szoros kapcsolatot) megalapozó Ilúvatar, más néven Eru, az Egyetlen. A kozmológiát tekintve Tolkien igen sokat merített a skandináv hagyományból. Az északi mitológia világa (háromszor) hármas tagolású, melynek vertikális és horizontális nézőpontból is a közepén helyezkedik el Miðgarð, amelytől északra a fagyos Niflheim, délre pedig a forró Múspel (Múspelsheim) nevezetü földrészek találhatók. Miðgarð szó szerinti jelentése „,bekerített közép”, melyről tudjuk, hogy az óriások elől fallal elkerített területet, az emberek hazáját jelöli (Sztyeblin-Kamenszkij 1985: 49-50). Elterjedtebb fordítása és egyben ismertebb neve „,a Középső Föld”, melyet Bernáth István „Középfölde” néven említ fordításaiban. Nyílt titok, hogy Tolkien ebből a szóból alkotta meg a maga „Középföldéjét” (Middle-earth), amely nem csak nevében, de jellegében is megfelel az óészaki változatnak. Tolkien esetében is a Föld (Arda) középső, az Emberek és Tündék (Ilúvatar „föisten” gyermekei, az egyszerübb összehasonlítás kedvéért: emberek) által lakott részét jelöli, ahol az istenek (Valák) nemigen járnak, legalábbis nem az emberekkel való kapcsolatteremtés céljából (Carter 2004: 52). Az emberek azonban kiszolgáltatott teremtmények, akiket a skandináv mitológiában többek között az óriások, Tolkien mitológiájában a gonosszá lett Vala, Melkor (a későbbi Morgoth) intrikái fenyegetnek - ezek ellen mindkét esetben az emberek védelmét önként vállaló istenek, a skandináv bór, valamint a tolkieni (bór istennel mind fizikai, mind személyiségbeli hasonlóságokat mutató) Tulkas és Oromë küzd (Tolkien 1999a: 417, 425).

A Múspel nevü déli, tüzes világrész nem ölt alaposabban kidolgozott alakot Tolkiennál: mitológiájának legelső, az 1910-es és 1920-as évekből való változatában esik ugyan szó az „forró, égő Délrôl”, ahol ember nem jár, ám a végleges, ma „A szilmarilok”-ként olvasható változatban csupán egy javarészt ismeretlen, déli, forró sivatagos világrészről tudunk, mely leginkább Afrikára emlékeztet (Wettstein 2002). Ezzel szemben a skandináv Niflheim Miðgarðhoz hasonlóan - nagyban befolyásolhatta Tolkien földrészeit: a keleti kontinens, a Valák Áldott Birodalma (Aman) északi részén elterülő jeges Helcaraxë hómező, mely a két kontinenst köti össze, egyben a gonosz Morgoth lakhelyének, Angbandnak is otthont ad, 
amely kísértetiesen hasonlít a skandináv Hel nevezetű alvilágra, ahová az út Niflheimen át vezet.

Vertikális tagolással ugyan nem él Tolkien (legalábbis nem úgy, mint a skandináv hagyomány), de a két mitológia egyes területei (,világok”) mégis összeegyeztethetők. Miðgarð fölött ugyanis Ásgarð helyezkedik el, az istenek vára (városa), mely fallal van elkerítve, és ahol minden istennek megvan a maga lakhelye. Ásgarð megfeleltethető a tolkieni Valinornak, még etimológiailag is hasonlítanak, hiszen Ásgarð nem más, mint „az ászok földje, lakhelye”, míg Valinor jelentése „a Valák (Erők) földje”. Az Ásgarðot körülvevő fal Tolkien esetében is megjelenik: a Pelórinak ugyanolyan védelmi funkciója van, mint Ásgarð falának (Wettstein 2002).

Ásgarð alatt az ,,alacsonyabb rendű istenek” helyezkednek el: közvetlenül az ászok alatt a ván istenek, alattuk pedig egyes álfok. Egy bizonyos fajta hierarchiát Tolkien mitológiájában is felfedezhetünk: teljes értékü lényekről van szó minden esetben, de mégsem egyenlők a Tündék, Maiák, Valák vagy a mindenekfelett álló Ilúvatar. Miðgarð alatt, észak-keletre Utgarð (Világszéle) fekszik, az óriások lakhelye. Ez a hely is általában veszélyes, elkerülendő helyként jelenik meg, a „gonosz, ártalmas és veszélyes” ugyanis mindig észak és kelet felől érkezik; ez Tolkien esetében is így van: „A szilmarilok” törénetében a fö ellenfél, Morgoth északon tanyázik, míg „A Gyürük Ura” Sauronja keleten, Mordorban alakítja ki fö erődítményét.

Tolkien nem tesz lényeges különbséget a Valákat illetően, legfeljebb fokozatilag, de alapvetően mégis egy csoport tagjai mind. A skandináv mitológia viszont két isten-típust különít el, az említett ászokat (æsir) és a vánokat (vanir). ${ }^{42}$ Tolkien esetében is jelen vannak az „istenszerü”, de alárendelt lények: a Maiák. A Maiák sok szempontból hasonlítanak a skandináv mitológiában található Világos Álfokhoz. A Világos Álfok és Sötét Álfok meglehetősen homályos szereplői a skandináv mitológiának, nem tudni, hányan vannak, nincs is túl nagy szerepük a történetekben, de ők is bírnak az istenekhez hasonló erővel, gyakran említik őket az istenekkel együtt: „Ászoknál mi újság? / Álfoknál mi újság?”, „Bajban ászok, / bajban az álfok!"43

\footnotetext{
${ }^{42} \mathrm{Az}$ ász istenek egy patriarchális népcsoport, az ún. csatabárdosok istenei, míg a vánok egy matriarchális kultúra hitvilágát képezték. Feltehetően a két népcsoport összecsapása, majd békekötése és közös letelepedése után a kultúrák összevegyültek és az így kialakult mitológiának két isten-típusa lett, ahol a legyőző nép (csatabárdosok) istenei maradtak dominánsok. Ász istenek: Óđin, Pór, Týr, Heimdal, Baldur, Bragi, Víðar, Váli, Ull, Hænir, Forseti, Loki. Ász istennők: Frigg, Iðun, Sága, Eir, Gefjun, Fulla, Nanna, Gero, Sjöfn, Lofn, Vár, Vör, Syn, Hlín, Snotra, Gná, Sól, Bil.

43 „, Prymskviða (brym-ének)”, 7. strófa és „Völuspá (A jósnő szava)”, 48. strófa (ford. Bernáth István) Az „Eddá”ban egyetlen nevesített álffal találkozunk, Völunddal, a „Völund-ének” („Völundarkviða”) főszereplöje.
} 
Magát a Tünde (Elf) elnevezést is a skandináv mitológiából vette át Tolkien, bár a név kivételével szinte semmi közös nem mondható el róluk. A Tündék alapvetően a kelta hagyományból eredeztethetők, és bár Tolkien is megkülönböztet „világos/fényes” Tündéket (Calaquendi/Elves of the Light) és „sötét” Tündéket (Moriquendi/Elves of the Darkness), ők mégis egy fajtához tartoznak, inkább csak kulturális, nyelvi és történeti különbségek akadnak köztük. Ezzel szemben a skandináv Világos és Sötét Álfok konkrétan elkülönített csoportokat alkotnak: a Világos Álfok jók, az istenek közösségébe valók, míg Sötét Álfok kifejezetten gonoszak, szokás a törpéket is hozzájuk sorolni.

A skandináv mitológia fontos részét képezik a különböző lények, csak úgy, mint Tolkiennál, de különbségek természetesen éppúgy akadnak, mint hasonlóságok. Skandináv mitikus lények az isteneken és embereken kívül a már említett álfok, az óriások, a törpék, trollok és a különböző neves szörnyek (a három legismertebb Loki gyermekei: a Fenrir farkas, $\mathrm{Hel}^{44}$ és a Jörmungand Világkígyó). Tolkien („A hobbit”-on kívül) nem igazán említ óriásokat, viszont a Törpök jellegzetességeit egyértelmüen az óészaki „törpefelfogás” alapján alakította ki. A skandináv mitológia törpéi a földből keltek ki (vagy Ýmir ősóriás húsából másztak ki férgekként), elméletileg teremtett lények, sok titok övezi kilétüket, hegyek földalatti üregeiben élnek, alacsony termetüek (ez egy viszonylag későn kialakult attribútumuk), értelmesek és ravaszok, nem ritkán gonoszak, bosszúvágyók. Nagyon fejlett kézügyességűek, mindenféle ékszert, fegyvert, csodás müszaki tárgyakat készítenek, nagy tehetséggel és becsvágyó szorgalommal kovácsolnak, sokszor az istenek megrendelésére. Ez a leírás tökéletesen illik a tolkieni Törpökre is, legalábbis az alacsonyabb rendüekre (Petty-Dwarves), mint például a Túrin-történetből ismert Mîm, aki épp úgy használ, mint árt a főhősnek és segítőinek (Tolkien 1998: 125). „A hobbit”-ból megismert Durin népe (Thorin és társai) is sok szempontból beleillik ebbe a leírásba, bár róluk korántsem mondható, hogy gonoszak lennének (Whittingham 2008: 64).

Az emberek megítélése más jellegű a két mitológiában, mégis vannak érdekes hasonlóságok. A skandináv mitológiában az emberek nem jutnak nagy szerephez, nem vegyülnek az istenekkel, nincs is átjárásuk hozzájuk (bár Miðgarðról a Bifröst nevü szivárványhíd Ásgarðba vezet), de mivel az istenek teremtették őket, egyfajta felelősséget is éreznek irántuk. Éppen ezért jár el Pór időnként Ásgarðból óriásokat ölni: nem volna jó, ha azok túlszaporodnának és veszélyeztetnék a Miðgarðon békésen élő vagy éppen egymással harcoló embereket. Talán e miatt a védelmező szerep miatt állt Pór isten közelebb a mindennapi

\footnotetext{
${ }^{44}$ Khtonikus lény; az alvilág félig holt, de szépséges úrnője, akit leginkább mégis szörnyként szokás említeni. 
életben az emberekhez, mint a többi főisten (Óðin, Týr, Frey). Tolkien esetében is igen fontos elem, hogy a Valák szívükön viselik Ilúvatar gyermekeinek sorsát, ezért lesz például a Tündék védelme és Valinorba hozatala a Morgoth-lakta Középfölde elleni támadás fő oka, melynek célja Morghot megfékezése, aki az egész világra kívánja kiterjeszteni hatalmát mely szándékban bizonyos értelemben sikerrel is jár. ${ }^{45}$ Tolkien írásaiban a Valák pártfogoltjainak két fő fizikai védelmezője van, Tulkas és Oromë, ilyen szempontból ők megfeleltethetők Pórnak, aki szintén hajlamos inkább fizikai erejével, semmint csellel, varázslattal felülkerekedni ellenfelén.

A panteon többi tagját csak meglehetősen önkényes alapokon lehetne összehasonlítani, bár a főistenek tekintetében sok hasonlóság elmondható. A skandináv főisten, Óðin rengeteg vonásában hasonlít Manwëre, és legalább annyi különbséget is mutatnak. Mindketten a lakóhelyük legmagasabb hegyének legmagasabb tornyában tartózkodnak, innen szemlélik a világot és elmélkednek. A tolkieni Vala vezető, Manwë az Oiolossë nevü toronyban székel, amely a legmagasabb hegyen, a Taniquetilen található, és innen követi figyelemmel a világ történéseit, még a különböző fizikai akadályokon keresztül is. Manwë mindenkinél messzebb lát, és gyakran hosszasan mereng magában, hogy megtudja, hogyan is kell a Valáknak cselekedniük: Manwë ugyanis emlékszik az Ainuk Muzsikájára, ${ }^{46}$ a zenére, ami megteremtette a világot, és amely magába foglalta a Föld teljes történetét az elejétől a végéig, még mielőtt gyakorlatilag is létrejött volna. Ily módon ismeri Manwë Ilúvatar Tervét. ${ }^{47}$ Óðin lakhelye a Hliðskjálf nevet viseli, ${ }^{48}$ itt található azonos nevü trónja. Ebből a toronyból alátekintve Óðin belátja az „összes világot”. ${ }^{49}$ Mindkét említett föisten rendelkezik egyéb hírforrással is, mint saját elméjük: Óðinnak két hollója, Hugin (gondolkodó) és Munin (emlékezö) hoz híreket a világ történéseiröl, Manwë pedig hasonló szolgálatokat kap a Sasoktól, illetve a széltől. Manwë azonban nem tekinthető az alvilág vagy a halottak urának, Óðinnal ellentétben - ilyen szempontból Mandos felelhetne meg Óðinnak, és Mandos

\footnotetext{
${ }^{45}$ Épp ahogyan Sauron tette az Egy Gyürüvel, Morgoth a Földbe (Arda) ágyazta hatalmát és lelkét. A folyamat több évezredet vett igénybe, $s$ végül az egész Föld mérgezetté vált, ezért szükséges annak teljes elpusztulása (majd újjászületése) a világ végekor (amire a továbbiakban még visszatérünk). Lásd Tolkien 1983-1996, 10. k.: „Morgoth's Ring”.

${ }^{46}$ Kezdetben Ilúvatar megteremtette az Ainukat (szellemi lények, a későbbi Valák), akik énekelni kezdenek, és folytatják az Ilúvatar által megkezdett dallamot, mely megteremti a Földet (kezdetben csak egy látomásként) és annak történetét. A zenére való emlékezés a jövőbe látást jelenti tehát, mely keveseknek adatott meg.

${ }^{47}$ Születéskor minden lélekkel rendelkező lény egy Ilúvatar által kijelölt sorsot kap.

${ }^{48}$ A név első tagja hlið ('nyílás, ablak'), a második, az óangol scylf alapján következtetett jelentése: 'magaslat, torony'.

49 Ásgarð (helyenként: Asaheim/Godheim), Vanaheim, Muspelheim, Miðgarð, Ljusalfheim, Svartalfheim, Jotunheim, Niflheim, Hel (utobbi hármat együttesen Utgarðnak szokás nevezni).
} 
(Mandos Csarnokai) a Valhöllnek, ${ }^{50}$ bár ez sokkal inkább emlékeztet a görög mitológia Hádészére, mintsem egy skandináv ihletésü istenre.

Óðin gyakran elhagyja otthonát, alakot tud váltani, el tudja hagyni testét, rengeteg álnéven ismert, és sokszor vándorol az emberek vagy éppen óriások között bottal járó, kék kalapos, hosszú, fehér szakállas öregembernek álcázva magát. Ez a leírás sokkal inkább emlékeztetheti a Tolkient olvasókat Gandalfra, mintsem Manwëre, éppen ezért szokás sokszor Gandalfot Óðinnal párhuzamba állítani (Carter 2004: 248-249), bár sokkal valószínűbbnek tủnik, hogy magát Gandalf alakját a finn Väinämöinen inspirálta (igaz, Väinämöinent szokás Óðinnal is összehasonlítani). Megint mások Óðin és Ilúvatar között keresnek egyezést: Óðin nevei között szerepel a gyakran felbukkanó Mindenek atyja (Allfaðir/Allfödr), mely sokak szerint megmagyarázza, hogy Tolkien mitológiájának legkorábbi változataiban miért az All-father nevet használja az általa később kitalált Ilúvatar helyett (Whittingham 2008: 42-43).

\section{Makar és Meássë; sorstudat, a világ vége}

Az első, 1910-es években megírt „A szilmarilok”-változatban („Elveszett Mesék Könyve”) az általunk ismert tizennégy Valából álló panteon kiegészült két másik szereplővel, nevezetesen Makar és Meássë alakjával, akik a harcok véres, kegyetlen istenei voltak. Az alábbi idézet jól bemutatja a két isten jellemét:

Hát íme! Felsoroltam, előszámoltam lakhelyeit mind a nagy Isteneknek, Aulë művei rendre, az ö tehetése-tudása érdeméből álltak Valinorban, ám Makar és tüzes nővére, Meássë külön építkezett, emeltek hajlékot csak a maguk népének ereje által, s komor is lett az a csarnok.

A Külső Földek határai szegélyezték, nem volt Mandostól sem messze. Vasból készült, dísztelen. Makar vazallusai ott vívtak vértben, és volt csengés, csattogás, kiáltozás, puffogás, döngés. Meássë elvegyült a harcolók közt, vadabb csatára bátorította őket, az ájulókat-gyengülőket fellocsolta, erős borral itatta, karja italtól-vértől vereslett. Istenek egyike sem fordult meg arra soha, Tulkászt kivéve, és ha Mandoszt látogatták, inkább vargabetút írtak le, útjuk cirkalmazták, csak e szörnyü lármát hallaniok ne kellene; de Tulkász olykor vítt ott Makarral, vagy keményen szétcsapott a bajvívók közt, erejét így gyakorolva, hogy ne lanyhulna; nem mintha azt a társaságot szerette volna, és öt sem kedvelték ott, épp nagy erejének okán.

Mármost Makar udvarában a bajvívás örökkön folyt, kivéve, ha lakomáztak a csarnokban, vagy, ha Makar s Meássë messze járt, vadászni ment medvét, farkast a fekete hegyekbe. Ám házuk tele volt mindennemü harci fegyverrel, nagy rendben sorakoztak a falakon a hatalmas, fénylö pajzsok. Fáklyák lángja világított, diadalénekek zengtek, lázas hangzatok, rablás-dúlás-pusztítás nótái harsogtak, és fáklyafény tükröződött a kardok vasán. Makar gyakran csak ült, hallgatva e harsogókat, térdén roppant bárd, keresztben, és Meássë dárdát szorongatott. Ám azokban a napokban, mikor Valinor elkészült, ezek ketten utaztak szerte a Föld színén, és gyakran jártak messze honuktól, mert a zürzavart kedvelték, melyet Melkó ${ }^{51}$ keltett szanaszéjjel a világon. ${ }^{52}$

\footnotetext{
${ }^{50}$ Más néven Valhalla vagy Walhalla. A valur 'elesett harcos' és a höll 'vár, csarnok' szavak összetétele.

51 „A szilmarilok”-ban: Melkor.

52 „Az elveszett mesék könyve”, 4. fejezet: A valák jövetele és Valinor építése (Tolkien 1996: 111-112, ford. Tandori Dezső).
} 
Könnyüszerrel felfedezhetünk határozottan vikingekre jellemző elemeket, valamint láthatunk szoros kapcsolatot a „kegyetlen Valák” csarnoka és a Valhöll között: Óðin csarnoka, a Valhöll nem más, mint a csatában elesett bátor harcosok túlvilági lakóhelye, melyet tüz helyett fénylő pengéjű kardok világítanak meg. Itt a valkyrják szolgálják ki a harcosokat, akik esznek-isznak, és naponta kilovagolnak életre-halálra harcot vívni, délutánra azonban feltámadnak és visszatérnek lakomázni. A Valhöllben összegyült harcosok (einherják) a világ végekor (Ragnarök) az istenek oldalán szállnak majd harcba az óriások ellen; ezért fontos, hogy minél több legyen belölük, aminek érdekében Óðin gyakran háborút szít az emberek között, egyik vagy másik félnek ígérve a győzelmet. A holtak ilyen fajta célszerü összegyüjtése nem jelenik meg Tolkiennál, azonban a világ végét, valamint a sorsot illetően nála is találunk hasonló motívumokat (Tolkien 2015b: I, 77-80).

Alapvető mitológiai párhuzam a mindkét helyen megjelenő erős sorstudat. A skandináv mitológiában mindenkinek meg van írva a sorsa, mindenkire ugyanaz vár: előbb-utóbb mindenki elpusztul, óriások, istenek, emberek és egyéb lények egyaránt. A világ vége pedig nem más, mint a híres Ragnarök (pontatlan, de elterjedt elnevezéssel az „Istenek Alkonya”), amikor is beteljesedik minden prófécia (amit a völvák [,jósnők”] jósolnak), értelmet nyer minden korábbi tett, és a déli világrész, Múspelsheim felöl Múspel fiai, a lángóriások az istenekre törnek. A jóslat szerint a sereg élén Surt áll majd, a lángóriások leghatalmasabbja, és az ő vezetésével átvágtatnak az emberek és istenek világát összekötő szivárványhídon, a Bifröstön, mely összeomlik a lánglovak patái alatt. Ekkor kerül sor a nevezetes párbajokra istenek és óriások, illetve szörnyek között, mint például Óðin viadala a Fenrir farkassal, Loki és Heimdal halála egymás keze által, vagy éppen Pór győzelme a Világkígyó felett, amit nem élvezhet sokáig, ugyanis kilenc lépés megtétele után a harc során ráfröccsent méreg megöli öt magát is - egy olyan elem, ami Tolkiennál a Túrin-történetben kerül elő (Tolkien 1999a: 251). A jövőt és saját sorsukat ismerik az istenek (gyakran még az istenek alatt elhelyezkedő népek is), és el is fogadják azt, bár olykor küzdenek ellene - hiába. ${ }^{53}$ A hasonló sorstudat határozottan jelen van Tolkiennál is, többször is kiderül egy-egy szövegrészböl: mindig minden úgy történik, hogy az elősegítse Ilúvatar tervét, illetve többször említésre kerül a „világ megváltozása”, mint minden eddigi dolgok vége. A világ vége pedig mindkét mitológiában akkor következik be, amikor az istenek ereje végleg elfogy, és már nem tudják fenntartani a rendet a világban (Whittingham 2008: 172-173).

\footnotetext{
${ }^{53}$ Ilyen például Fenrir lekötözése, vagy Pór kísérlete a Világkígyó kihalászására („Hymiskviða/Hymir-ének”).
} 
A skandináv mitológiából nagyon fontos átvétel Tolkien esetében ez a fajta isteni erő csökkenése, ami azonos módon müködik mindkét esetben. Az ász istenek ereje egyértelmüen fogy, ez sok mindenböl kitünik: először is feltünő, hogy amit kezdetben megteremtenek az istenek, azt többé nem tudják pont úgy előállítani: az emberek megteremtésekor Óðin adott életet az első emberpárnak, aminek következtében ő maga „meg lett fosztva tőle”, így vált ő a Holtak urává is. Értelmet a Hænir nevü ász istentől kaptak az emberek, de ezért cserébe Hænir elvesztette bölcsességét, és csupán akkor tudott a többi isten elött okosként megjelenni, ha vele volt a Mímir nevü bölcs lény (miután kiderült, hogy önmagában kifejezetten buta Hænir, az istenek gúnyt üztek belőle). Amikor a Fenrir farkast láncra verik, hogy ne árthasson az isteneknek a Ragnarök során (természetesen fölösleges próbálkozás), a harmadik, legerősebb láncot, a Gleipnirt a törpék készítették „macskaléptek zajából, nők szakállából, hegyek gyökeréből, halak sóhajából, medveinakból és madarak nyálából” (Bernáth 2011: 87) - ezek a dolgok éppen ezért már nem léteznek, állítja Snorri Sturluson a „Próza Eddá”-ban. Maga a Ragnarök is azért következik be, mert az istenek egyre kevésbé uralják önmagukat, sorsukat, egyre többet vétkeznek, míg végül már tehetetlenek, és végleg elgyengülve nem tudják megállítani az óriások támadását (Michelsen/Røskeland 2002). Bár kevéssé ismert, de Tolkien is írt egy világvége történetet, ráadásul több változatban is. Ezt Tolkien Dagor Dagorathnak [Csaták csatája] nevezte, alapja pedig ennek is az, hogy a Valák kifogynak teremtőképességükből, ugyanis az óészaki istenekhez hasonlóan nekik is fogy az erejük, méghozzá nagyon hasonló módon: amikor a szent fényforrást, a valinori Két Fát Melkor elpusztítja egy pókszerű szörny, Ungoliant segítségével, a Valák határozottan képtelenek újat teremteni, Yavanna csak a szilmarilok fényének felhasználásával tudná meggyógyítani a fákat. Ugyanígy a szilmarilok is éppen azért olyan értékesek, mert a kovácsok kovácsa, Fëanor összes teremtő erejét beléjük öntötte a Két Fa fényével együtt, ezzel képtelen lett bármi más „varázserőt” igénylő dolog létrehozására. Ebből a konfliktusból, valamint Fëanor kapzsiságából adódik a szilmarilokért folytatott harc, valamint Valák és Tündék valódi felkelése Morgoth ellen. De végül beteljesül Ilúvatar terve, véget ér a világ, bekövetkezik a végső összecsapás, a Dagor Dagorath, mégpedig az alábbi idézetben leírt módon:

Mikor a Világ megöregszik és az Erők elfáradnak, Morgoth visszatér az Ajtón át az Időtlen Sötétségből; elpusztítja a Napot és a Holdat, de Eärendil ellene támad, és kiüzi őt a levegőégből. Ekkor vívják meg az utolsó csatát Valinor síkján. Azon a napon Tulkas birokra kel Melkóval, jobbján áll majd Fionwë, balján pedig Túrin Turambar, Húrin fia, a Sors Legyőzője, és Túrin fekete kardja okozza majd Melkó halálát, és végső pusztulását. Így bosszultatnak meg Húrin gyermekei, és minden ember.

Ezután összegyüjtik a Szilmarilokat a tengerből, a föld mélyéből és a levegőégből; mert Eärendil alászáll, és visszaadja a gondjaira bízott lángot. Ekkor Fëanor magához veszi a Hármat, és átadja 
őket Yavanna Paluriennek; ő megtöri öket, és tüzükkel újjáéleszti a Két Fát, és nagy fényesség gyúl majd; Valinor hegyeit lebontják, így a fény szétárad a világban. Ebben a fényben az istenek megfiatalodnak, a tündék felébrednek, minden halottjuk felkel, és beteljesednek velük Ilúvatar tervei. De az embereket azon a napon a prófécia nem említi, csak Túrint, és öt az istenek közé sorolja. $^{54}$

Érdekes, hogy a Tolkien által jóváhagyott utolsó „A szilmarilok” változatban még szerepel a Dagor Dagorath, de Christopher Tolkien végül kihúzta belöle, így ez ma „hivatalosan” már csak a „Középfölde históriája” címü könyvsorozatban olvasható. Mindenesetre az idézett leírásból látható, hogy a tolkieni világ vége egyszerre tartalmazza germán-skandináv Ragnarök és a keresztény végítélet elemeit (Whittingham 2008: 177-184).

\section{A kisebb, esetlegesebb átvételek}

Ezek az elemek teljesen véletlenszerünek tünhetnek, gyakran Tolkien saját maga szórakoztatására illesztette őket bele müveibe, így egy kis meglepetést okozva az adott témákban jártasabb olvasóknak és - elsősorban - saját magának. Tolkien köztudottan szeretett teljes történeteket, hosszú fejezetnyi leírásokat alkotni csak azért, hogy az elbeszélés során egy helyen alkalmazhasson egy olyan (gyakran igen apró) motívumot, fordulatot, amit annyira megkedvelt egy adott mítosz olvasása során, hogy úgy érezte, muszáj beleillesztenie saját mitológiájába is. A legtöbb ilyen elemet „A szilmarilok”-ban találjuk: ez a mü természetesen Tolkien legösszetettebb (már ha külön kívánjuk kezelni őket) alkotása, melynek rengeteg jelensége párosítható sok más mitológiában megjelenő jelenséggel (nem kizárólag az északi világképpel), miközben természetesen az sem lehetetlen, hogy Tolkien teljes egészében önmagától alkotta meg és írta bele azokat történeteibe. A feltünő esetek többségében azonban igen egyszerüen elképzelhető, hogy egyik vagy másik (esetünkben északi) mítosz ihlette meg az alkotót.

Ilyen például a tolkieni Carcharoth és Morgoth jelensége. Morgoth mindenféle tekintetben emlékeztet a skandináv mitológiából ismert Lokira. Mindketten egy speciális mitikus karakter, az ún. trickster szerepkörével rendelkeznek: alapvetően isteni eredetűek, sokat segítenek kezdetben az isteneknek, de sokat is ártanak - kezdetben pusztán azért, mert zavarja őket a túlzott békesség, vidámság, az idők haladtával azonban már irigységből, sőt, pusztán kedvtelésből, gonoszságból követnek el egyre nagyobb gaztetteket. Ravaszok, gyakran cselek révén csapnak be más szereplőket, annak ellenére, hogy kezdetben igen fontos szerepet játszanak az istenek világának megalkotásában. Loki egyre gonoszabb dolgokat müvel, ahogy

\footnotetext{
54 Mandos próféciája; „Középfölde históriája: Középfölde formálása” („The History of Middle-earth: The Shaping of Middle-earth") (ford. Tolkien Társaság).
} 
a Ragnarök közeledik, mígnem végül az ászok úgy döntenek, elfogják és megkötözik. Béklyóitól csak a világ végekor szabadul, és az istenek ellen száll hadba. Mind a jellem, mind az események párhuzamba állíthatók Morgothszal, bár meg kell jegyezni, Loki alakja nagyon sokrétü, nem pontosan egyértelmü, mikor miért is szerepel az egyes mítoszokban, de vitathatatlanul ő jelenik meg leggyakrabban a történetek során, és ő személyesíti meg a lázadást, a konfliktust és a káoszt. E tekintetben szerepköre pontosan egyezik Morgothéval.

Loki nevéhez füződik továbbá a három (részben már említett) alvilági szörny létrehozása: a Fenrir farkas, a Jörmungand Világkígyó és Hel, az azonos nevet viselő alvilág úrnője. Fölösleges is talán említeni, de természetesen „A szilmarilok”-ban Morgoth hozza létre a gonoszabbnál gonoszabb szörnyeket, gondoljunk csak a Balrogokra, a sárkányokra, vagy éppen „Morgoth kutyájára”, Carcharothra. Ezek közül a legtöbb párhuzam Fenrir és Carcharoth között vonható. Mindketten a legnagyobb farkasok, végtelenül gonoszak és hasonló módon ártanak ellenfelüknek: Fenrir (miközben az ászok lekötözik őt) ${ }^{55}$ leharapja Týr isten jobb kezét, ami hatalmas gond, mert Týrt, az igazság istenét így erejétől fosztják meg, hiszen a régi germán kultúrában a jobb kéz szolgált az ítélet kihirdetésére: az igazságszolgáltatásra. Hasonló motívum jelenik meg Tolkien esetében a Beren és Lúthien történetben: miután az egyik szilmarilt visszaszerezték Morgothtól, Berenék Angbandból (Morgoth erődítménye) kifelé menet Carcharothszal találkoznak, aki leharapja Beren jobb kezét és lenyeli a szilmarillal együtt (Tolkien 1999a: 189-221). Itt is érezhető az erős értékvesztés, bár más jellegü, mint a skandináv mitológiában, sokkal elvontabban értelmezendő.

Sokkal konkrétabb átvétel lehet az istenek hazájába vezető híd jelensége, már pusztán azért is, mert ez egyike Tolkien személyes kedvenceinek. A skandináv mitológiában Miðgarðról a már említett Bifröst szivárványhíd vezet Ásgarðba, melyet kizárólag az istenek használhatnak, és melynek végében az istenek őre, Heimdal figyeli, nem támadnak-e az óriások. Tolkiennál is megjelenik egy hasonló híd, melyet az emberek védelmezője Oromë hoz létre az isteni város, Valinor elrejtésekor (Tolkien 1999a: 337). A híd neve Ilwaren („Mennyek Hídja”; a szivárvány Quenya ${ }^{56}$ megfelelője), melyet szintén kizárólag a tolkieni istenek, a Valák és segítőik, a Maiák használhatnak (Whittingham 2008: 111). A Bifröst-hídat Tolkien több levelében és esszéjében is említi, sőt, szinte minden történetében szerepelnek hidak, melyek

\footnotetext{
${ }^{55}$ Szinte minden mitológiában előkerül a lekötözött isten képe. Tolkiennál is a gonosszá lett istent, Morgotht kötözik meg a Valák.

${ }^{56} \mathrm{Az}$ egyik Tolkien által alkotott Tünde nyelv.
} 
különböző „világokat” kötnek össze; az „On Fairy-Stories” címü cikkében a valóságot és a fantáziát összekötő hídnak nevezi a Bifröstöt (Tolkien 1997: 378).

Szembetűnőek továbbá a híres fegyverek és neveik. A skandináv mitológiában és Tolkien esetében is nagyon fontos, hogy minden igazán erős fegyver saját névvel rendelkezik, nevében hordozza elsődleges erejét és jellemét. A kardokon, pajzsokon, lándzsákon általában rúnák is találhatóak, amelyek erősítik a kard erejét. Mindkét mitológiában beszédesek a kardnevek, utalhatnak egy-egy tettre vagy tulajdonságokra (például az arra érdemesek kezében „önmagától kaszaboló” kard, mely a skandináv Frey isten tulajdonában állt, amíg el nem ajándékozta), ez Tolkiennál is észrevehető (például „A hobbit”-ból jól ismert Glamdring, azaz az Ellenségkalapáló [Foe-hammer], vagy a Koboldhasító Orcrist [Goblin-cleaver], melyek olyan híresek voltak, hogy az Orkok maguk is adtak nekik nevet saját nyelvükön). Elég, ha csak Fingolfin híres párviadalára gondolunk Morgoth ellen: természetesen mindkét félnek híres-neves fegyvere van, Fingolfin Ringil („Hideg Csillag”, vagy „Hideg Szikra”) ${ }^{57}$ nevü kardjával sebzi meg Morgoth lábát, Morgoth pedig Grond („Bunkósbot”) nevü hatalmas pörölyével száll hadba, mely hatalmas krátert hoz létre minden egyes alkalommal, amikor lesújt (Tolkien 1999a: 179). A skandináv mitológiából jól ismert, hasonló erővel és jelleggel bíró fegyver például Óðin lándzsája, Gungnir („Kaszaboló”), mely a tolkieni Gil-galad lándzsájára, Aeglosra („Jégcsap”) emlékeztet; Pór kalapácsa, a Mjöllnir (zúzó, őrlő) vagy Sigurð kardja, Garm, melyet Regin kovácsolt újra, és mely sok tekintetben emlékeztet a Tolkien világából ismert Aragorn törött, majd újjá kovácsolt kardjára, az Andúrilra („Nyugat Lángja”). Kardok tekintetében igen jó példa továbbá Túrin Turambar kardja, Gurthang 58 („Halál Vasa”): ez a kard nem pusztán saját ,jellemmel” bír, de a történet tetőpontján meg is szólal, és szinte önmagától cselekszik - gyorsan, saját bevallása szerint szívesen oltja ki gazdája, Túrin életét, miközben igazságtételként tekint e tettére:

[Túrin] Azzal kihúzta kardját, és így szólt:

- Légy üdvözölve Gurthang, Halál Vasa, mert immár egyedül te maradtál meg számomra! De te ismersz-e más szolgálatot vagy hüséget, mint hogy engedelmeskedj a kéznek, amely megragad? Senki vérétől nem riadsz te vissza! Készen vagy-e kiontani Túrin Turambarét is? Készen vagy-e rá, hogy gyorsan végezz velem?

A pengéből jéghideg hang válaszolt:

- Igen, kész vagyok meginni véred, hogy végre elfelejthessem az én gazdám, Beleg és a méltatlanul legyilkolt Brandir vérének ízét. Ígérem, gyors halálod lesz. (Tolkien 2014: 250)

\footnotetext{
$57 \mathrm{Az}$ alább következő, idézőjelben, magyarul megadott fegyvernevek az angol név alapján készített saját fordításaim.

${ }^{58}$ Eredeti nevén Anglachel, melyet Eöl kovácsolt és adott Thingolnak. Felesége, Melian említi, hogy a „kovács sötét lelke benne él a kardban”, és balszerencsét fog hozni viselőjére.
} 
Gurthang önállósága a történet során az ász isten, Frey magától kaszaboló kardjára emlékeztet.

Ezek a fegyverek (az olyan egyéb varázstárgyakon kívül, mint Óðin Draupnir ${ }^{59}$ nevü gyürüje, és az Egy Gyürü) mind Tolkien, mind a skandináv mitológia esetében rúnákkal díszítettek, melyek varázserővel bírnak. Maguknak a tolkieni rúnáknak a kérdése igen összetett, több szakirodalom is említi, hogy Tolkien a vikingkori rúnaábécét, a FUTHARKot vette át, ez azonban nem egyértelmü, $\mathrm{s}$ bővebb kifejtésére ebben a dolgozatban nincsen mód. Mindenesetre a rúnák mint a modern fantasy elengedhetetlen kellékei talán a tolkieni hagyaték legelterjedtebb jelensége.

Akad továbbá egy név, Eärendil, a legendás tünde harcos és tengerész neve, aki gyakorlatilag „A szilmarilok” főszereplője. Ö a közvetítő ,,istenek” és „,emberek” között, aki a történet végén a Valák honából nem térhet vissza Középföldére, hanem hajóján az utolsó, el nem veszett szilmarilt szállítva az ég boltozatán utazzon és világítson azok számára, akik továbbra is a Nagy Ellenség, Morgoth elnyomása alatt sínylődnek - így vált Eärendil csillaggá, ahogy azt „A Gyürük Urá”-ban is említik. Maga a név történetesen a germán mitológia egyik csillagának a neve is egyben, mint azt Viktor Rydbergtől, a germán mitológia kutatójától tudjuk: az Earendel vagy Orvandel nem más, mint az Esthajnalcsillag (Rydberg: 1906: 768769). A név absztrakt jelentést kapott, majd az óangol nyelvben azt jelentette: ragyogás. A „Codex Exoniensis”-ben felbukkant egy régi himnusz töredékében, melyet Tolkien így fordított:

Eala Earendel, engla beorhtast

Ofer Middangeard Monnum sended.
Hail Earendel, brightest of angels, sent over Middle-earth to men. ${ }^{60}$

Egyes humoros, ám egyáltalán nem alaptalan megjegyzések szerint Tolkien azért írta meg az egész szilmarilok-történetet, hogy ez az általa oly kedvelt négy sor elhangozhasson és értelmet nyerhessen a történet csúcspontján. Az mindenesetre vitathatatlan, hogy Tolkien igen gyakran alkotott meg egész élettörténeteket kizárólag azért, hogy felhasználhassa forrásainak egy-egy általa arra érdemesnek tartott részletét - a leghíresebb ilyen bizonyára maga „A Gyürük Ura” hat könyve, melynek fö célja „A hobbit” összekötése a több évtizede alakuló, de nem publikált tolkieni mitológiával („A szilmarilok”-kal), valamint mindkét történet folytatása volt (Carter 2004: 221-225).

\footnotetext{
59 Törpék által készített értékes varázsgyürü, mely minden kilencedik éjjel nyolc magával azonos gyürüt „csöppent ki magából”.

${ }_{60}$ „O, Orvandel, angyalok legfényesebbike / Te, kit középföld fölé küldtek az embereknek.” (Ford. Réz Ádám) 


\section{A skandináv mitológia elemei Tolkien mitológiájában - az önállóbb történetek}

A legtöbb, legfeltünőbb germán-skandináv elemet azonban egyértelmüen „A hobbit”-ban találjuk. Ez nem véletlen: „A hobbit” megírásakor Tolkien éppen az Eddákat, izlandi sagákat tanulmányozta, és örömest csempészett egy-két érdekes elemet saját müvébe, melyet nem kiadásra, csupán alkalmi esti mesének szánt. Ne feledjük, „A hobbit” megjelenése 1937, ami épp abba az évtizedbe esik, amikor Tolkien a Völsunga- és Guðrúnarkviðával, valamint a különböző „,viking klubokon” belül az „Eddá”-k és egyes óizlandi sagák fordításával foglalkozott. Tolkien bátran merített a skandináv mitológiából gyerekeinek alkotott esti meséihez, ugyanis ekkor még nem kívánta „A hobbit”-ot bármi féle módon „hivatalos” mitológiájához kötni (ebből később sok gondja is származott a „hitelesítés” során, melynek végeredménye „A Gyürük Ura” lett - közel húsz évvel később). Ezért is furcsállhatják „,A szilmarilok”-at „A hobbit” előtt olvasók például azt, hogy Hobbitok, Középfölde manapság minden bizonnyal legkedveltebb népei egyáltalán nincsenek megemlítve benne. A Törpök mibenlétét már említettük az előző fejezetben, ez természetesen javarészt illik Tölgypajzsos Thorin társaságára is. Sokkal érdekesebb viszont az a tény, hogy a Gandalf megnevezés és a Törpök nevei szinte egy az egyben szerepelnek a „Verses Edda” első és talán leghíresebb szövegében, a „Völuspá”-ban [A jósnő szava]. A vers tartalmáról most annyit érdemes tudni, hogy az ászok által a halálból felébresztett völva [jósnő] a világ kezdetéről, az egyes fontos eseményekről és a világ végéről beszél, tehát nem csak jóslatokat fogalmaz meg, hanem a múltba is visszatekint, így alkotva egy nagyjából egységesnek mondható északi mitológiai világképet (Carter 2004: 202-204).

\section{A nevek}

Az, hogy Tolkien az „Eddá”-ból vette át a Törpök nevét, sosem volt igazán titok. Ezt ugyanis több levelében is említi, amellett, hogy magának a műnek a művészi értékét vonja kétségbe: „Jómagam nem tartom túl sokra »A hobbit«-ot, minthogy jobban kedvelem a saját mitológiámat (amelyre itt épp csak kitérek), a maga tömör névanyagával... mint ezeket a »Völuspá«-ból kiemelt, eddikus nevü törpéket, újkeletű hobbitokat és (egy tétlen órában teremtett) gollamokat, valamint angolszász rúnákat."

A „Völuspá” tízedik versszakától kezdődik a beszélő névvel rendelkező törpék felsorolása, mely Bernáth István fordításában az alábbi módon olvasható.

$$
\text { Par var Mótsognir Kedvszívó lett }
$$

\footnotetext{
${ }^{61}$ Tolkien 2009: 4. Tolkien levele egyik barátjának, 1937. december. (Ford. P. K.)
} 
meztr um orðinn dverga allra, en Durinn annarr. beir mannlíkön mörg um gørðu, dvergar, ór jörðu, sem Durinn sagði.

Nýi ok Niði, Norðri ok Suðri, Austri ok Vestri, Alpjófr, Dvalinn, [Nár ok Náinn, Nípingr, Dáinn,] Bífurr, Báfurr, Bömburr, Nóri, Án ok Ánarr, Ái, Mjöðvitnir.

Veigr ok Gandalfr, Vindalfr, Práinn, Pekkr ok Porinn, prór, Litr ok Vitr, Nár ok Nýráor, nú hefi ek dverga, Reginn ok Ráðsviðr, rétt um talða.

\section{Fíli, Kíli,}

Fundinn, Náli, Hepti, Vúli, Hanarr, Svíorr, [Nár ok Náinn, Nípingr, Dáinn, Billingr, Brúni, Bíldr ok Búri,] Frár, Hornbori, Frógr ok Lóni, Aurvangr, Jari, Eikinskjaldi.

Mál er dverga í Dvalins liði ljóna kindum til Lofars telja, peir er sóttu frá salar steini Aurvanga sjöt til Jöruvalla.

Par var Draupnir ok Dolgprasir, Hár, Haugspori, Hlévangr, Glóinn, [Dóri, Óri, legfőbb és első minden törpe közt, második Szundi. Több emberalakot formáztak törpének, ahogy Szundi mondta, agyagos földböl

Újhold, Óhold, Észak, Dél, Kelet, Nyugat, Lopós, Lomha, [...]

\section{Ügyes, Bajos,} Testes, Poronty, Öreg, Vénebb, Nagyapó, Mézlopó.

Makacs, Vajákos, Markos, Szélfuvó, Kedves, Színes, Merész, Jól-élő, Bölcs, Tudós, Gyilkos, Tanácsadó, Uras ezzel a törpéket jól előszámláltam.

\section{Ráspoly, Véső,} Reszelö, Rálelö, Kovács, Nyílfaragó, Kürtfúró, Szikrázó, $[\ldots]$

Fényes, Csatázó, Fürge, Jókezü, Tủgyártó, Híres, Tölgyfa-pajzsos.

Mondom mindenkinek most a törpéket Lomha csapatából, egész Dicsmondóig, kik kőházaikból, Kavicsos részből, vonultak át Viadal-mezőre.

Köztük Aranymíves, Káromló, Védőr, Szikrás, Színezö, Hadakozó, Izzó, [...] 
Dúfr, Andvari,]

Skirvir, Virvir

Skáfiðr, Ái.

Álfr ok Yngvi,

Eikinskjaldi,

Fjalarr ok Frosti,

Finnr ok Ginnarr.

Sírba-lépő,

Drágakő, Nagyapó.

Álf és társa, Yngvi,

Tölgyfa-pajzsos,

Álnok, Dérverte,

bat mun uppi,

meðan öld lifir,

Ámító, Lappangó -

Dicsmondó sarjait,

sorról-sorra,

langniðja tal

míg világ a világ,

Lofars hafat.

észben megőrzik. ${ }^{62}$

A szövegben sok olyan név (például Durin, Dáin) szerepel, amit Tolkien szintén felhasznált mitológiájában, de az egyszerüség kedvéért most csak „A hobbit”-ban szerepelő fontosabb nevek vannak félkövér betükkel feltüntetve.

A kérdés már csak az, hogyan fér össze Tolkien hitelesítésével az a tény, hogy a Törpöknek viking neveik vannak. A válasz: a Törpök titokban tartják neveiket, ezért a mindennapi érintkezés során egy embernevet vesznek fel, méghozzá az északi emberek szokásai alapján. Ezek a nevek pedig a „fordítás” során keletkeztek - Tolkien ugyanis hasonlóra „fordított” (a hitelesítési kerettörténete az, hogy ő tulajdonképpen csak lefordította a történeteket, amiket a Tündék, Hobbitok írtak) minden olyan nyelvet, ami az óangollal rokonítható, ezzel érzékeltetve azt, mennyit érthetett egy hobbit például a rohírok ${ }^{63}$ beszédéböl - nagyjából annyit tehát, mint amennyit a mai angol beszélők értenek az óangolból. Germán legendákban gyakran szokás a név elrejtése is, sok „Edda-dal”-ban, sagában ugyanis a névnek magának hatalma van. Valakinek a nevét ismerni annyit jelentett: ismerni egész történetét, erejét, adott esetben pedig meg lehetett átkozni az illetőt. Ha egy haldokló ellenfelét nevén szólítva átkozza el, sokkal valószínübb, hogy az átok megfogan, ez világosan kiderül többek között a „Völsunga sagá”-ból. Óðinnak például több mint ötven álneve volt, bár nem kizárólag az említett okból. Hasonló jelenet játszódik le Bilbo és Smaug beszélgetése során (Tolkien 1999b: 198-216), mint a híres Sárkányölő Sigurð és a Fáfnir sárkány találkozásakor: mindkét esetben igyekeznek a hősök elrejteni valódi kilétüket, ezzel védve magukat. Ugyanez a motívum figyelhető meg Túrin esetében is: Túrin (aki életútját tekintve kísértetiesen hasonlít Sigurðra) álnevek felvételével igyekszik elkerülni végzetes sorsát (Morgoth átkát), többek között a legendás és gonosz sárkány, a Fáfnirról mintázott Glaurunggal való találkozásakor is. Érdekes továbbá, hogy Túrin pontosan olyan hadicsellel győzi le Glaurungot, mint Sigurð Fáfnirt: alulról támad, és a sárkány gyengepontját, a hasát hasítja fel (Tolkien 2008: 238). A

\footnotetext{
${ }^{62}$ „Völuspá”, 10-16. strófa (ford. Bernáth István).

${ }^{63}$ Lovas népcsoport. Az angolszász eoh szó jelentése: ló, mely sok rohani névben megjelenik, valamint a saját maguk által létrehozott Éorlingas megnevezésben is felbukkan.
} 
párbaj egy másik skandináv történetre is emlékeztet: végeredménye párhuzamba állítható Pór isten és a Világkígyó közötti párbaj eredményével: a hős sikeresen legyőzi a sárkány(kígyó)t, de annak mérge rácsöppen testére, s így a földre kerül. Pór kilenc lépés megtétele után bele is hal a méreg okozta sebekbe, míg Túrin csak eszméletét veszti: nemes vére és barátai segítő varázslata ugyanis megmentik életét - bár végül kiderül, csupán azért, hogy Túrin még egy utolsó hatalmas csalódást éljen át. Belátja, hogy minden igyekezete ellenére Morgoth átkát nem sikerült elkerülnie: Glaurung (halála előtt) felfedte a titkot, miszerint Túrin felesége, Nienor nem más, mint saját húga, aki a sárkány varázslata alatt állt, s nem emlékezett arra, ki is ő valójában. A varázslat megtörik a szörny halálával, s Nienor - ismét öntudatra ébredve egy folyóba veti magát. Túrin ezek után nem hajlandó tovább élni bűneivel ${ }^{64}$ és saját húga, valamint egyetlen barátja, Beleg megölésének tudatával, így végül bekövetkezik a fentebb idézet öngyilkosság.

Ugyanebből a történetből említhetünk még egy elemet, amely kísértetiesen hasonlít egy északi mitológiai elemre: Túrin sisakja, egy fajta rémsisak (helmet of terror), mely olyan erős félelmet ébreszt viselője ellenfeleiben, hogy azoknak esélyük sincs többé legyőzniük őt. A Völsunga saga említi, hogy Fáfnirnak volt egy sisakja, mely félelmet ébresztett mindenkiben, aki rápillantott, és kénytelen volt menekülni, ahogy a sisak felbukkan a közelben. Ez a sisak kerül Sigurðhoz, miután legyőzi a sárkányt. Túrin sisakja ezen kívül még annyiban hasonlít Fáfniréhoz, hogy sárkányfej alakja van, aminek nevét is köszönheti: a dor-lómini ${ }^{65}$ sárkánysisak (Dragon-helm of dor-Lómin) (Drout 2006: 474).

A sárkány motívuma többször is elökerül Tolkien mítoszai során, ezeknek természetesen van skandináv alapjuk, de, mint a rúnák esetében, ez is egy összetettebb elem, mindenesetre közös vonás, hogy a germán sárkányok is eszesek, gonoszak, hasukon sebezhetők, kincset őriznek, és a legkisebb aranyérem eltünését is észreveszik, még alvás közben is.

Túrin története („Húrin gyermekei”) hangulatát és formáját tekintve minden bizonnyal Tolkien „leggermánabb” szövege, noha tartalmilag szinte egy az egyben megegyezik a „Kalevala” egyik mítoszával. Maga az említett sorstudat, jóslat (vagy éppen átok), valamint a sors ellen való hiábavaló küzdelem, melyet a skandináv mitológiából olyan jól ismerhetünk, ebben a tragikus, tolkieni történetben rajzolódik ki a legmarkánsabban. Érdekes, hogy ez a történet, mely egyike „A szilmarilok” „négy nagy történetének”, ${ }^{66}$ legalább öt eltérő

\footnotetext{
${ }^{64}$ Annak ellenére, hogy Túrin alapvetően pozitív karakter, tragikus és bűnös sors jut neki: Morgoth átkának következtében akaratlanul is saját családja és barátai elárulójává és gyilkosává válik noha egész életében a tragikus sors elkerüléséért küzd - hiába.

${ }^{65}$ Dor-Lómin: Húrin (Túrin apja) birodalma, Túrin otthona, melyet Orkok és Glaurung dúl fel.

${ }^{66}$ Túrin-történet, Beren és Lúthien története, Gondolin bukása, Eärendil története.
} 
változatban létezik: egy található „A szilmarilok”-ban, egy (az előzőnél valamivel hosszabb) a „Befejezetlen Regék”-ben, egyet külön kiadásban jelentetett meg Christopher Tolkien néhány évvel ezelött, ezeken kívül pedig legalább kettő rövidebb, verses formában megírt változatban, mely (egyelőre) nem elérhető. A történet eredeti címe továbbá „Túrin Saga”, később „The Saga of Túrin” [Túrin sagája/Túrin története] volt, mely további bizonyíték Tolkien és az óizlandi sagák szorosabb kapcsolatára (Drout 2006: 475).

\section{Szópárbajok, mitikus lények, helyszínek}

„A hobbit” egyik legszórakoztatóbb, legközkedveltebb része, a találós kérdés párbaj Bilbo és Gollam között, egyértelműen eredeztethető a skandináv történetekből. Egyik levelében Tolkien „,bevallja”, hogy ehhez a jelenethez a „Fáfnismál” (Tandori Dezső fordításában: „Fáfnirölő Szigurd éneke”) és más „Edda-dalok” szolgáltak ihletként (Drout 2006: 473). Maguk a skandináv ász istenek is különböznek szellemi és a fizikai erő kérdésében, tudjuk például, hogy Pór a legerősebb, a csodafegyverekkel bíró, óriásölő harcos, aki könnyen haragra lobban, és lassan csillapul, és nem is túlzottan agyafúrt. Ezzel szemben Óðin a leleményesség és tudás megtestesítője, az „Edda-versek”-ben többször is felbukkan a „szellemi hadviselésének” jelentősége. A „többet ésszel, mint erővel” szólást tökéletesen bemutató „Vafprúðnismál”-ban („Vafprúðnir-ének”) Óðin felkeresi a Vafprúðnir nevű bölcs óriást - tudáspárbaj céljából. A párbaj természetesen életre-halálra megy, Óðin természetesen álnéven (Vándor) érkezik. Az ének során kölcsönösen találós kérdéseket tesznek fel egymásnak, amelyek elsősorban természeti jelenségekre, személyekre, fontos eseményekre és a világ teremtésére vonatkoznak. Érdekes, hogy a szópárbaj végén Óðin cselhez folyamodik: olyat kérdez, amit csak ő tudhat: „Mit súgott Óđin máglyára rakott fiának fülébe?” - az említett fiú Baldur, akit Loki ármánykodása következtében testvére, a Höð nevü egy éves, vak isten ölt meg. Kérdéses, hogy egyáltalán súgott-e valami Óðin, a lényeg mindenesetre az, hogy ebből a kérdésből az óriás rájön, hogy magával a Mindentudó Óđinnal párbajozik, tehát kilátástalan helyzetben van, készül a halálra. Talán nem is kell részletezni, mennyire hasonlít ez a jelenet Bilbo és Gollam párbajára, ahol szinte pontosan ez a jelenet ismétlődik meg, azzal a kivétellel, hogy Gollam nem igazán akarja betartani a fogadás rá vonatkozó feltételét inkább csalással fizetne a csalásért (Tolkien 1999b: 66-85, Wettstein 2002).

Tolkien a sárkányokon és törpéken kívül egyéb lényeket is átemelt a skandináv mitológiából „A hobbit”-ba. Ilyenek a Trollok. A skandináv mitológia szereplői, a trollok tulajdonképpen óriások, de nem a jól ismert gonosz, erőszakos, hatalmas, északon élő déróriásokra kell gondolnunk. Sokkal inkább az alábbi módon kell őket elképzelnünk: hegyek között laknak, 
rejtett kincset őriznek, csúfak, nagytermetűek, erősek, de nagyon ostobák, gyakran ártanak az embereknek: elrabolják jószágaikat, és nem ritkán vétkesek emberevésben is. A későbbi hagyományokban törpékkel hozták őket párhuzamba; nem mindig egyértelmü, hogy egy adott történet negatív szereplöje pontosan micsoda: óriás, déróriás, törpe, sötét álf, troll? Mindenesetre egy híres szópárbaj során Pór egy törpét (lehet, hogy troll) úgy győz le, hogy addig húzza a kérdéseket, míg a Nap felkel, és így ellenfele kővé változik:
Egyetlen szájból
Ennyi ös szókincset
soha nem hallottam.
De bevált cselem,
jól becsaptalak -
tüz rád a napfény,
törpe, neked véged! ${ }^{67}$

Ezek szerint tehát fontos jellemzője néhány gonosz lénynek, hogy napfény hatására kővé válnak, ez történik „A hobbit”-ban is, amikor a három Troll - melyek azonos attribútumokkal rendelkeznek, mint a skandináv trollok - vacsorát szeretne készíteni Thorinékból, de Gandalf csele révén végül addig vitatkoznak, amíg reggel nem lesz, és kővé nem válnak (Tolkien 1999b: 28-43). A mai izlandi nyelvben egy külön ige van annak kifejezésére, hogy valaki „kővé válik, ha eléri a hajnal” (Sztyeblin-Kamenszkij 1985: 82): „daga uppi” (Thráinsson 2007: 207).

„A hobbit”-ban óriásokat is említ Tolkien, ez különös, ugyanis a többi írásában nem igen kerülnek elő. Az „Edda-versek”-ben találkozunk egy hasonló résszel, amikor Frey isten elküldi szolgáját, Skírnirt, hogy kérje meg számára egy óriáslány, Gerð kezét: Skírnirnek egy ködös, esős hegyen kell átkelnie, ahol sok veszély várja, többek között útonálló óriások és a hegyekben élő óriások és gonosz lények titkos üregei, csapdái. Hasonló veszélyek várnak Bilboékra a Ködhegységen (Misty Mountains) való átkelés során, ahol az Orkok el is fogják a társaságot. A „Skírnismál”-ban [Skírnir-ének] Frey odaadja saját kardját szolgájának, hogy az segítse veszélyes útján. Maga a kard (Lævatein) átruházása Skírnirre hiba Frey részéröl: magától kaszaboló kardját elvesztvén nem képes megvédeni magát a Ragnarökkor, s így életét veszti - ennek azonban tudatában volt, vállalta a következményeket. Ez több versből is kitünik, például a „Verses Edda” nyolcadik énekéből, a „Loki csúfolódik”-ból, melyben a Myrkviðr (Mirkwood) is megjelenik (Carter 2004: 219-220):

Loki (Freynek):

Aranyért nyerted el

${ }^{67}$ „Alvíssmál” [Alvís-ének], 35. strófa (ford. Bernáth István). 
Gymir lányát is, kardod meg kölcsönadtad mihez fogsz majd, botor, ha a Múspel-fiak befutnak a Feketeerdő [Myrkviðr] felől? ${ }^{68}$

De a Ködhegység (Misty Mountains) és a Bakacsinerdő/Setéterdő (Mirkwood) nem az egyetlen helyszín, melyet Tolkien a germán hagyományból vett át. Ide sorolható még a Magányos Hegy (Lonely Mountain), mely Smaugnak és kincshalmának ad otthont, és mely egyértelműen a harmadik és negyedik fejezetben említett óangol hőseposzból, a „Beowulf”ból került át Tolkien történetébe. Továbbá említhetjük még Beorn csarnokát is: szokás skandináv eredetet tulajdonítani Beornnak, bár erősebbnek tünik az angolszász hatás. A név jelentése „medve”, Beorn csarnokának leírása pedig megegyezik egy viking uradalmi csarnok leírásával, és harcmodorából kitünik a mágikus erővel bíró viking harcosok (berserkerek) hadviselési módja. A berserkerek örjöngő harcosok, akik mindenféle tudatmódosító szerek használatával vadállatként vetették magukat az ellenség csapatai közé. Etimológiailag az elnevezés első tagja is a 'medve' szót tartalmazza, ami nem csoda, hiszen az északi történetek igen kedvelt szereplői a medvék és farkasok: északon ezek az állatok rendelkeztek a legnagyobb presztízzsel. „A hobbit”-ban ezt is észrevehetjük, ahol egy külön faj képviselői a Wargok - a varg szó pedig a mai napig farkast jelent skandináv nyelveken.

A skandináv mitológia, különösen a Sigurð-legenda és „A hobbit” párhuzamait régóta kutatják, bár a témát gyakran nem kellő körültekintéssel kezelik, ráadásul sokszor kizárólag Wagnert tekintik viszonyítási és összehasonlítási pontnak. Lin Carter - „Tolkien és a Gyürük Ura világa" címü müvében - az alábbi pontokban foglalja össze kissé pontatlan, leegyszerűsített elméletét „A hobbit” és a wagneri Siegfried-történet hasonlóságairól:

1. Egy sárkány kincset öriz.

2. A varázserővel bíró gyürü, amely rettentő hatalmat ad viselőjének, de halálos átkot hordoz.

3. Egy láthatatlanná tévő talizmán, amely a kincshez társul.

4. A sárkány megölése a mellkasán lévő, védtelen részen keresztül.

5. A kettétört kard, amely ismét egésszé lesz.

6. A két törpe, illetve a két óriás közti veszekedés a Gyürü birtoklásáért.

7. A Gyürüt birtokló gonosz kis törpe megőrül, és a személyisége eltorzul, végül megölik a talizmánért.

\footnotetext{
${ }^{68}$ Bernáth 2011: 252 (42. strófa).
} 
8. A jelenség, hogy a Gyürü Átka nem csupán halált hoz a viselőjére, hanem egyfajta erkölcsi romlást is, illetve hogy aki egyszer birtokolja, az örökkön-örökké mohón vágyik rá. (Carter 2004: 213)

A Siegfried-történet azonban rengeteg pontban eltér a Tolkien által felhasznált északi változattól, a Sigurð-történettől, s mint említettük, Tolkien nem használta fel (már pusztán személyes ellenszenvből sem) Wagner változatát, kizárólag az óészaki vonalat követte. Ennek ellenére a két hőstörténet lényegében ugyanabból az alapból nőtt ki, és mindenképpen feltűnő, könnyen látható hasonlóságokat tartalmaz „A hobbit” is (ha nem is annyit, mint például a „Húrin gyermekei”), melyek azonban nem minden esetben túlzottan megalapozottak. Sok elem kifejezetten nem az óészaki kultúrából, hanem az említett „Beowulf”-ból kerül át, amit Lin Carter is elismer (Carter 2004: 214).

\section{A „Gyürük Ura” egzotikumai}

„A Gyürük Urá”-ban sokkal rejtettebb, finomabb kivitelezésű germán elemeket találunk, mint „A szilmarilok”-ban vagy „A hobbit”-ban, ugyanakkor ezek is rendkívül érdekesek lehetnek. Érthető, hogy Tolkien nagyobb hangsúlyt fektetett a teljes mértékben saját ötletekre „A Gyürűk Ura” esetében, ez volt ugyanis az első megrendelésre írt, kiadásra szánt könyve, míg egészen idáig szigorúan szabadidejében írt, maga és gyermekei számára. Itt is találkozhatunk „A szilmarilok”-ból ismert kozmológiával, teológiával, eszkatológiával, ám itt mindez a háttérben áll, csak említés szintjén utal rájuk egyszer-egyszer egyik-másik szereplő - ráadásul gyakran olyan utalásokat (jóslatok, csillagok és csillagképek, híres ütközetek, neves hősök és más karakterek, a világ nagy eseményei, a Tündék és Valák tevékenységei stb.) tesznek, melyek egyáltalán nem is nyernek értelmet, ha az olvasó kizárólag „A Gyürük Urá”-ból indul ki. Ezen felül viszontláthatunk egy sor, „A hobbit”-ból és egyéb önállóbb történetből ismert északi ihletésű szereplőt: Wargokat, neves kardokat, Trollokat, északi eredetü neveket (rohírok és törpök) és sok más említett skandináv elemet (Carter 2004: 199-251), de ezek mellett jóval kevésbé feltűnő átvételek is felfedezhetők.

Egy meglehetősen rejtélyes, kizárólag „A Gyürük Urá”-ban felbukkanó eseménnyel találkozunk a Sírbuckáknál (Barrow-Downs) történtek során (Tolkien 2007b: 176). Ekkor ugyanis egy ún. buckamanó (Barrow-wight) elfogja a négy Hobbitot, és lakhelyén, egy ősi időkből származó kardokkal és kincseshalmokkal teli sír belsejében tartja őket fogva, mígnem a misztikus Bombadil Toma (Tom Bombadill) megérkezik, és ráolvasással elpusztítja a gonosz szellemet. Óizlandi sagákban több helyen is előfordul, hogy egy-egy sírt gonosz 
lények (vættr - nem feltétlenül emberi lények) őriznek, hogy a nem kívánatos látogatókat, sírrablókat távol tartsák. Ezek a lények gyakran draugök („kísértet, fantom”), az északi mitológia jellegzetes szereplői, afféle óészaki zombik. A draug egy olyan ember, aki halála után ismét életre kel, és vagy saját sírhelyét őrzi, vagy kerít magának egy másik (lehetőleg több, értékesebb kinccsel rendelkező) sírt, ahová beköltözhet. A draugök általában gonosz, veszélyes lények, melyek gyakran varázserővel bírnak, így különböző átkokat szórhatnak áldozataikra. ${ }^{69}$ Egyes sagák főhőseinek olykor meg kell küzdeniük ilyen draugökkel, ez a küzdelem pedig gyakran értelmezhető morális szinten is, ugyanis egy draug legyőzése után a sír tartalma (fegyverek, kincsek stb.) jogosan azé a hősé, aki - adott esetben varázslattal, fortéllyal - legyőzte a sír gonosz őrzőjét: hőstettet hajtott végre, és nem sorolható a közönséges sírrablók közé. Hasonló módon jutnak végül „A Gyürük Ura” Hobbitjai is fegyverekhez a buckamanóval való találkozást követően (Tolkien 2007b: 194).

A leghíresebb draugök többek között a „Grettis sagá”-ból ismert Glam, a ,jóindulatú” Gunnar a „Njáls sagá”-ból (magyarul: „A felperzselt tanya”), valamint Angantyr a „Hervararkviðá”ból. ${ }^{70}$ Maga a buckamanó eredeti, angol neve, a Barrow-wight először a fentebb említett William Morris „Grettis saga”-fordításában bukkan elő, nem véletlen hát, hogy Tolkien éppen ezt a nevet választotta saját élőhalottjai számára (Drout 2006: 473-474). A halottak bizonyos szinten való jelenlétét az evilági életben természetesen egyik mitológia sem tarthatja kizárólag sajátjának, ugyanakkor vitathatatlan a rengeteg hasonlóság a draugök és a tolkieni buckamanók között.

Egy hasonlóan óészaki elem „A Gyürük Urá”-ban Sauron alakja, mint alattvalóinak gyürüket osztó úr. A vikingkorban az urak feladata és kiváltsága volt harcosaik, hű követőik megjutalmazása, közöttük a zsákmány felosztása egy-egy csata után. A zsákmány, illetve ajándékok lehettek kardok, más fegyverek, kincsek, pénz (arany vagy ezüst) vagy bármi más, ami értékkel bírt - mindezen dolgok együttes gyüjtőneve gyakran a ring, azaz a gyürü volt, mely egyáltalán nem csak a hüséget jelképező viking karperecre (armring) vonatkozott, hanem minden olyan jutalomra, amit a vezér osztott. Ebből a hagyományból alakult ki, hogy a vezéreket, urakat, kiskirályokat (jarl) a gyürü adó, vagy gyürü osztó kenninggel illették. Ez a kenning rengeteg óizlandi sagában és „Edda-dal”-ban, sőt a „Beowulf”-ban és egyéb óangol szövegekben is előfordul; úgy tünik, ez a szó egy egészen hétköznapi szinonima lehetett az említett magas rangú urak megnevezésére (Wettstein 2002). A gyürü maga továbbá a legértékesebb kincsek közé tartozott valamennyi germán kultúrában, és így a közös germán

\footnotetext{
${ }^{69} \mathrm{https}: / /$ sv.wikipedia.org/wiki/Draug (21.03.2017)

${ }^{70} \mathrm{https}$ ://en.wikipedia.org/wiki/Barrow-wight (21.03.2017)
} 
mitológiai hagyományban is: nem egy alapvető északi mítoszban játszik föszerepet egy-egy híresebb gyürü, mint például az említett Draupnir, vagy Andvari gyürüje. Az, hogy Sauron - a Gyürük Ura - épp gyürük, méghozzá a Hatalom Gyürüi (Rings of Power) által béklyózza magához Embereket (gondolunk itt a Nazgûlokra) és szilárdítja meg azok kényszerhűségét, több szempontból is megfeleltethető tehát az óészaki kultúrából ismert gyürü adónak.

Egy másik érdekességet fedezhetünk fel, ha összevetjük a Peter Jackson által rendezett filmben található beszédet, melyet Aragorn szaval el a Fekete Kapu (The Black Gate, Morannon) elött, és a már említett Völuspá azon részét, amely bevezeti a Ragnarököt. Aragorn filmbeli beszéde említi a „farkasok óráját” (,an hour of wolves”), a „pajzsok hasadását” („shattered shields”) és az „emberek korának végét” („the age of men comes crashing down”). A „Völuspá”-ban pedig ez áll a Ragnarök bekövetkeztére vonatkozó strófákban:

Testvér tör testvérre,
eltiporják egymást,
rokonságot rokon
ront szanaszét.
Ronda egy világ lesz,
ringyólkodás kora,
kardok-fejszék kora,
pattannak szét pajzsok,
farkas-kor, vihar-kor,
széthull a világ.
Senki a másiknak
soha nem kegyelmez. ${ }^{71}$

Ez azért érdekes, mert a Kolbítar csoport saját fordításának részleteiről beszélhetünk, melyet Tolkien a „The Elder Edda” című egyetemi előadásai során említett (Whittingham 2008: 25). Ez a fordítás méghozzá igen alapos: ugyanis Tolkienék az „emberek korának” (age of men) végét emlegetik, ami szó szerinti fordítás (ellentétben az összes többi angol, illetve magyar nyelvü fordítástól), hiszen a veröld „,világ” (helyenként verǫld, verøld; vö. a. world) óészaki szó nem más, mint a „ver” („ember”, vö. lat. vir) és az „öld” („kor, időszak, idő”) szavak összetétele. ${ }^{72}$ Bár Tolkien ezt a beszédet ilyen formában nem írta bele „A Gyűrűk Ura” ötödik könyvébe, sok eleme mégis megjelenik Theoden király beszédében pár fejezettel korábban, valamint „A szilmarilok”-ban, a Finrod Felagund és Sauron közötti párbajt leíró dalban. ${ }^{73}$

Végül egy szintén igen rejtett „ínyencségről” érdemes szót ejteni, melyet már részben érintettek a korábbi fejezetek. Az, hogy Tolkien ismerte és tudta helyesen alkalmazni a régi

\footnotetext{
${ }^{71}$ „Völuspá”, 45. strófa (ford. Bernáth István).

$72 \mathrm{http}: / /$ runeberg.org/svetym/1261.html (2017.01.07.)

${ }^{73}$ Tolkien 2007c: 1096, „Lay of Leithian” [Leithian-ének]. 
germán verselést, a fornyrðislagot, már kellő bizonyosságot nyert a „Völsungakviða en nýja” és a „Guðrúnarkviða en nýja” bemutatásakor. De későbbi írói tevékenysége során, úgy tünik, mindössze egyetlen egyszer alkalmazta ezt a tudását: Tolkien belecsempészett pár strófányi fornyrðislagot legismertebb művébe, „A Gyürük Urá”-ba, mégpedig az Entek verseibe. Bár a későbbi szerkesztés, valamint Szilszakáll pillanatnyi bizonytalanságai („Hm, hm, hm”) megakasztják a strófikusságot, a rövid-hosszú sorok (a fornyrðislag alapegységei), az alliterációk és a szabályos szótagszámok jól látszanak. Ne feledjük, hogy maga a fornyrðislag jelentése „régi beszéd”, valamint azt, hogy az Entek Középfölde legidősebb teremtményei közé tartoznak (ők a „legidősebb beszélő lények”), így igen találó nyelvükre a „régi beszéd” megnevezést alkalmazni (Drout 2006: 164). Tolkien ráadásul általában a hármas alliteráció szabályát követi, ezáltal követve a szigorúbb elöírásokat:

Learn now the lore of Living Creatures!

First name the four, the free peoples:

Eldest of all, the elf-children;

Dwarf the delver, dark are his houses [...]

(Tolkien 2007: 604)
Tanuld e tant, Eleven Lényekét!

Négy nevet mondj, a szabad emberekét:

A legrégebbiek a tünde-ivadékok,

Turkáló törpök, házuk homályos [...]

(Ford. Tandori Dezső)

\section{7. Összefoglalás - Tolkien, a hagyományteremtő}

Ezek volnának tehát a Tolkien müveiben legpontosabban azonosítható átvételek az óészaki kultúrából, a skandináv mitológiából. Természetesen nem Tolkien volt az első müvész, aki az északi pogány hitvilág és kultúra egyes elemeit önkényes módon, azokat kisebb-nagyobb mértékben átalakítva, vagy esetleg egy az egyben átvéve felhasználta saját fikciós műveiben. Még csak az sem állítható, ahogy az első fejezetekben láthattuk, hogy Tolkien lett volna az egyetlen olyan író és művész, aki az általános és alapvető ismereteken kívül igazán mély szaktudással is rendelkezett a témában: Tolkien előtt is akadtak, akik szintén jártasak voltak a skandináv mitológiában és az óizlandi irodalomban, s így apró északi elemeket rejthettek el egy-egy müben, melyek a legtöbbeknek talán egyáltalán fel sem tűnnek. Már William Morrisnál is találkozhatunk Mirkwoddal, egy Gandolf, a Medve nevü karakterrel vagy akár a Völsungokkal, sőt, korábban, a portugálok nagy lovagregényében, az „Amadís de Gaulá”-ban a szintén eddikus eredetü Dán Durin név is felbukkan (Carter 2004: 221). Az azonban vitathatatlan, hogy a régi germán hagyomány (ideértve neveket, isteneket, mítoszokat, mitikus helyszíneket, jelenségeket, rúnákat, varázstárgyakat) iparrá válása a modern fantasyirodalomban egy olyan folyamat, melynek egyik első megindítója és legnagyobb úttörője J. R. R. Tolkien volt. Az, hogy Tolkien milyen nagy hatással volt és van ma is a fantasyirodalomra, valamint magára a fantasyre mint kulturális jelenségre, nem lehet témája ennek a 
dolgozatnak, ami bizonyára nem igényel több magyarázatot az eddig elhangzottaknál. Ahhoz azonban, hogy érzékeljük Tolkien feltétlen jelenlétét napjainkban is, elegendö körül néznünk az internet fantasyt érintő világában és az egyes könyvesboltokban, ahol Tolkien könyvei mind fordításokban, mind eredeti nyelven a választék állandó tagjai - immár fél évszázada. Tolkien presztízsét olyan jelenségek is bizonyítják, mint napjaink első számú high-fantasy sorozatának és egyben a nemzetközi bestseller lista vezetőjének, a „Tủz és jég dalá”-nak könyvenként 5-20 oldalas ajánlói, melyekből egyértelműen és egyhangúlag az sugárzik, hogy mind a kritikusok, mind az olvasók egyetlenegy személlyel tudnák összehasonlítani a szerző, George R. R. Martin nevét és érdemeit: J. R. R. Tolkiennal.

\section{Irodalomjegyzék}

Ács, Péter/Baksy, Péter (2010): A központi skandináv nyelvek történetének vázlata a kezdetektől a reformációig. Budapest: ELTE Germanisztikai Intézet.

Bernáth, István (2011): Skandináv mitológia. Budapest: Corvina.

Carter, Lin (2004): Tolkien és A Gyürük Ura világa. Szeged: Szukits.

Drout, Michael D. C. (2006): J. R. R. Tolkien Encyclopedia. New York: Routledge, https://doi.org/10.4324/9780203961513

Edda (1985) (ford. Tandori Dezső). Budapest: Európa.

Enoksen, Lars Magnar (1998): Runor. Lund: Historiska Media.

Hume, Kathryn (1984): Fantasy and Mimesis. Responses to Reality in Western Literature. New York/London: Methuen.

Hutterer, Miklós (1986): A germán nyelvek. Budapest: Gondolat.

Jackson, Rosemary (1981): Fantasy: The Literature of Subversion. New York/London: Methuen, https://doi.org/10.4324/9780203328446

Király, István (főszerk.) (1970-): Világirodalmi lexikon (II., III., IV., VIII., XII. kötet). Budapest: Akadémiai.

Lassen, Annette (2008): Det norrøne og det nationale. Reykjavík: Stofnun Vigdísar Finnbogadóttur í erlendum tungumálum.

Lothe, Jakob/Refsum, Christian/Solberg, Unni (2007): Litteraturvitenskapelig leksikon. Oslo: Kunnskapsforl.

Mácsik, Gábor (2012): A skandináv mitológia. Miskolc: Könyvmühely.

Mészöly, Ágnes (2015): Határérték. Budapest: KRE Bölcsészettudományi Kar. 
Michelsen, Per-Arne; Røskeland, Marianne (szerk.) (2002): Forklaringer: litterære tekster lest på nytt. Bergen: Fagbokforlaget.

Olsson, Bernt/Algulin, Ingemar (1995): Litteraturens historia i Sverige. Stockholm: Norstedts 1995.

Omdal, Gerd Karin (2010): Grenseerfaringer: fantastisk litteratur i Norge og omegn. Bergen: Fagbokforlaget.

Ridderstrøm, Helge (2017): In: http://edu.hioa.no/helgerid/litteraturogmedieleksikon/fantasylitteratur.pdf (2017.12.29.).

Rydberg, Viktor (1906): Teutonic Mythology. Gods and Goddesses of the Northland. London: Norrœna Society, 3. k.

Shippey, Tom (2000): J. R. R. Tolkien: Author of the Century. London: HarperCollins.

Stiftler, William L. (1991): Experiments in Genre: Fantasy and Mimesis in Stephen R. Donaldson. Chattanooga: University of Tennessee.

Sztyeblin-Kamenszkij, M. I. (1985): A mítosz. Budapest: Kozmosz Könyvek.

Thráinsson, Höskuldur (2007): The Syntax of Icelandic. Cambridge: Cambridge University Press, https://doi.org/10.1017/CBO9780511619441

Todorov, Tzvetan (2002): Bevezetés a fantasztikus irodalomba. Budapest: Napvilág.

Tolkien, Christopher (1983-1996): The History of Middle-earth. London: George Allan \& Unwin.

Tolkien, J. R. R. (1996): Az elveszett mesék könyve I-II. Szerk. Christopher Tolkien. Kaposvár: Holló és Társa.

Tolkien, J. R. R. (1997): Tales from the Perilous Realm. Szerk. Christopher Tolkien. London: HarperCollins.

Tolkien, J. R. R. (1998): Unifnished Tales. Szerk. Christopher Tolkien. London: HarperCollins.

Tolkien, J. R. R. (1999a): The Silmarillion. Szerk. Christopher Tolkien. London: HarperCollins.

Tolkien, J. R. R. (1999b): The Hobbit. London: HarperCollins.

Tolkien, J. R. R. (2003a): A Gyürük Ura. Szerk. Christopher Tolkien. Budapest: Európa.

Tolkien, J. R. R. (2003b): A szilmarilok. Szerk. Christopher Tolkien. Budapest: Európa.

Tolkien, J. R. R. (2007a): The Lord of the Rings. London: HarperCollins.

Tolkien, J. R. R. (2007b): The Fellowship of the Ring. London: HarperCollins.

Tolkien, J. R. R. (2007c): The Return of the King. London: HarperCollins. 
Tolkien, J. R. R. (2008): The Children of Húrin. Szerk. Christopher Tolkien. London: HarperCollins.

Tolkien, J. R. R. (2009): The Legend of Sigurd and Gudrún. Szerk. Christopher Tolkien. London: HarperCollins.

Tolkien, J. R. R. (2012): A hobbit. Szerk. Christopher Tolkien Budapest: Európa.

Tolkien, J. R. R. (2014): Befejezetlen regék Númenorról és Középföldéről. Budapest: Európa.

Tolkien, J. R. R. (2015a): Beowulf: Fordítás és kommentár. Szerk. Christopher Tolkien. Budapest: Európa.

Tolkien, J. R. R. (2015b): The Book of Lost Tales I-II. Szerk. Christopher Tolkien. London: HarperCollins.

Voigt, Vilmos (2016): Óizlandi irodalom és kultúra. Budapest: ELTE Germanisztikai Intézet. Völsunga saga (2015): A Völsungok története (ford. Bernáth István). Budapest: Corvina.

Wettstein, Martin (2002): Old Norse elements in the works of J.R.R. Tolkien. In:

http://www.academia.edu/228734/Norse_Elements_in_the_work_of_J.R.R._Tolkien (2016.12.29.).

Whittingham, Elizabeth A. (2008): The Evolution of Tolkien's Mythology. Jefferson: McFarland \& Co. 